\title{
Characterization of Radionuclides in Waste Sludges from High Level Waste Tanks 40, 42, and 51
}

by

R. F. O'Bryant

Westinghouse Savannah River Company

Savannah River Site

Aiken, South Carolina 29808

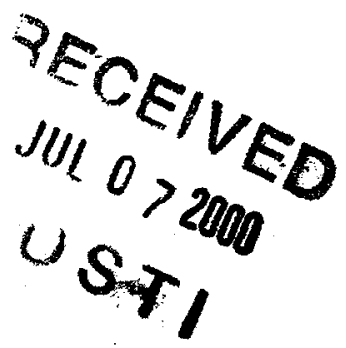

This paper was prepared in connection with work done under the above contract number with the U.S. Department of Energy. By acceptance of this paper, the publisher and/or recipient acknowledges the U. S. Government's right to retain a nonexclusive, royalty-free license in and to any copyright covering this paper, along with the right to reproduce and to authorize others to reproduce all or part of the copyrighted paper. 


\section{DISCLAIMER}

This report was prepared as an account of work sponsored by an agency of the United States Government. Neither the United States Government nor any agency thereof, nor any of their employees, makes any warranty, express or implied, or assumes any legal liability or responsibility for the accuracy, completeness, or usefulness of any information, apparatus, product or process disclosed, or represents that its use would not infringe privately owned rights. Reference herein to any specific commercial product, process or service by trade name, trademark, manufacturer, or otherwise does not necessarily constitute or imply its endorsement, recommendation, or favoring by the United States Government or any agency thereof. The views and opinions of authors expressed herein do not necessarily state or reflect those of the United States Government or any agency thereof.

This report has been reproduced directly from the best available copy.

Available for sale to the public, in paper, from: U.S. Department of Commerce, National Technical Information Service, 5285 Port Royal Road, Springfield, VA 22161

phone: (800) 553-6847

fax: (703) 605-6900

email: orders@ntis.fedworld.gov

online ordering: http://www.ntis.gov/ordering.htm

Available electronically at http://www.doe.gov/bridge

Available for a processing fee to U.S. Department of Energy and its contractors, in paper, from: U.S. Department of Energy, Office of Scientific and Technical Information, P.O. Box 62, Oak Ridge, TN 37831-0062

phone: (865)576-8401

fax: $(865) 576-5728$

email: reports@adonis.osti.gov 


\section{DISCLAIMER}

Portions of this document may be illegible in electronic image products. Images are produced from the best available original document. 
This page cannot be converted.

Please view the native document

for the original page. 


\section{TABLE OF CONTENTS}

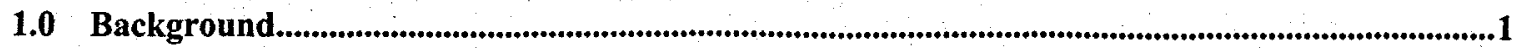

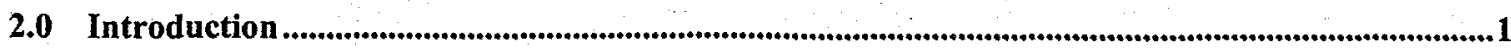

\subsection{Development of a Radionuclide Distribution for Sludge Fraction of Sludge-Contaminated}

Waste.....

3.1 Determining the Initial List of Radionuclides

3.2 Consolidating Sludge from Tanks 40, 42 and 51

3.3 Excluding Radionuclides from Consideration

3.4 Development of a Distribution

3.5 Other WAC Criteria

3.5.1 Comparison to Package Guidelines

3.5.2 Sum of Fractions Calculation

3.5.3 Nuclear Criticality Safety Criteria

3.5.4 Class C Waste Determination

3.6 Documentation of the Distribution

4.0 Supernate Fraction of Sludge-Contaminated Waste

4.1 Radionuclide Distribution

4.2 Other WAC Criteria

4.3 Documentation of the Supernate Fraction Distribution

5.0 Quantification

5.1 Quantification of Sludge and Supernate Fractions

5.2 Quantification of Job Control Waste and other Compactable Sludge-Contaminated Waste

5.3 Quantification of Non-Compactable Sludge-Contaminated Waste

6.0 Periodic Review and Validation

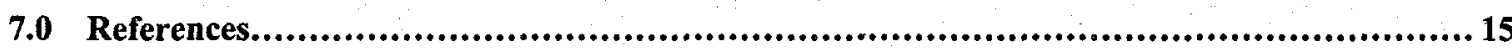




\section{ATTACHMENTS}

Attachment 1 Attachment 2 Attachment 3 Attachment 4 Attachment 5 Attachment 6 Attachment 7

Development of Scaling Factors for Tanks 40,42 and 51 Comparison of Tanks 40, 42 and 51 for Consolidation Sludge Waste Stream 40/42/51, Exclusion Criteria Sludge Waste Stream 40/42/51, Developing the Final List of Radionuclides Waste Characterization Form for Sludge Fraction, WPT-00002-51 Waste Characterization Form for Supernate Fraction, WPT-00001 Sludge Waste Stream 40/42/51, Sludge and Supernate Fractions Activity Distributions

\section{LIST OF TABLES}

Table 3.1 Radionuclides Important to Characterization of the Sludge Fraction of SludgeContaminated Waste

Table 3.2 Tanks 40, 42 and 51 Historical Data

Table 3.3 Radionuclides Excluded from Consideration, Sludge Fraction

Table 3.4 Radionuclide Scaling Factors and Distribution for Waste Sludge from Tanks 40, 42 and 51

Table 3.5 Calculation of Blended Activities for Waste Stream 40/42/51

Table 3.6

Table 3.7 Comparison of Sludge Fraction of Sludge=Contaminated Waste to LAWV Limits

Table 3.8

Table 3.9 Sum-of-Fractions for Sludge Fraction of Sludge-Contaminated Waste Calculation of FGE Equivalent for Sludge Fraction of Sludge-Contaminated Waste Class C Waste Analysis for Sludge Fraction of Sludge-Contaminated Waste

Table 4.1 


\section{Background}

Characterization of High Level Waste Sludge by the Concentration Storage and Transfer (CST) Department is outlined in WSRC-TR-94-0579, High Level Waste Sludge Characterization in Support of Low Level Waste Certification (Reference 1). The sludge characterization is based on a series of scaling factors for 31 of 34 known sludge-containing waste tanks. Scaling factors were previously compiled and compared with available sample data in WSRC-TR-94-0562, Characterization of Radionuclides in HLW Sludge Based on Isotopic Distribution in Irradiated Assemblies (Reference 2). Quantification of sludge-contaminated waste and application of the scaling factors has been performed on a case-by-case basis since approval of the methodology by the Waste Characterization Board in 1994. Scaling factors have been applied to each waste tank individually.

Further examination of historical tank use data contained in the "Waste Transfers and Additions Database," TR93425 b.xls (Reference 3), tank contents (i.e. high heat or low heat fractions of either Purex or H-Modified waste) and waste age (both in Reference 2) allowed consolidation of sludge in waste tanks to be considered.

Procedure WAC 2.02, Low Level, Hazardous, Mixed and PCB Waste Characterization Requirements, Rev. 4 (Reference 4) allows for consolidation of waste streams when the following two criteria are met:

1. Performance Assessment (PA) radionuclide scaling factors do not vary from the proposed data set scaling factor by more than a factor of 10 , and

2. The fractional activity of the predominant radionuclides (predominant radionuclides being those that make up $10 \%$ or greater of the activity) in each data set does not vary by more than a factor of 2 from the fractional activity of the same radionuclide in the proposed data set.

This document contains one such proposed consolidation of sludge-contaminated waste generated from High Level Waste Tanks 40, 42 and 51.

\section{Introduction}

Sludge-contaminated waste consists of waste contaminated with both insoluble species (the sludge fraction) and interstitial supernate. $75-90 \%$ of the weight of what is commonly referred to as sludge is interstitial supernate; the remaining 10-25\% consists of the insoluble species (Reference 1).

Development of a method for characterization of sludge-contaminated waste must consider both fractions. Separate waste cuts may contain sludge and supernate fractions in varying proportions due to the nature of the job generating the waste and the variability in waste handling techniques. Development of a distribution representative of all sludge-contaminated waste cuts must allow for varying fractions of sludge and supernate contamination.

This document will develop a radionuclide distribution for the sludge fraction of sludgecontaminated waste stored in High Level Waste Tanks 40,42 and 51 in accordance with the methodology outlined in WAC 2.02 (Rev. 4). A single, comprehensive characterization for supernate has been developed previously (Reference 5). This distribution is based on the assumption that sludge-contaminated waste from tanks 40,42 and 51 may be co-mingled, and the actual contamination present on waste in a series of containers from these tanks will be representative of the mean radionuclide distribution. 
This document also describes the methodology for application of radionuclide distributions representative of the sludge and supernate fractions of sludge-contaminated waste to individual waste packages.

Most of the waste contaminated with sludge from Tanks 40,42 and 51 will be categorized as Low Level Waste (LLW) and disposed of in the E-area Vaults (EAV). The waste does, however, have the potential to be categorized as TRU and/or mixed waste. Quantification of hazardous constituents and determination of whether the waste is classified as mixed is dependent on the amount of sludge and supernate present on the waste matrix and the nature of the waste matrix, and will be performed on a case-by-case basis. Quantification of radionuclides present in each waste package will be performed as described in Section 5.0.

The radionuclide distribution developed for LLW contaminated with sludge from Tanks 40, 42 and 51 can also be applied to waste classified as transuranic. [Neither WAC 3.06, E-Area TRU Pads Transuranic Waste Acceptance Criteria, Rev. 5 nor Appendix A:34, TRU Waste Container Characterization Form (OSR 29-90) Instruction specifies a methodology for determination of the isotopic distribution in TRU Waste; simply that the methodology be documented.]

This characterization is based primarily on available sample data for tank 42 and 51 . Periodic validation of the distribution developed in this document will be performed as discussed in Section 6.

Development of a Radionuclide Distribution for Sludge Fraction of Sludge-Contaminated Waste

The development of the radionuclide distribution in this section is performed per guidance outlined in WAC 2.02, Low Level, Hazardous, Mixed and PCB Waste Characterization Requirements, Rev. 4 (Reference 4).

\subsection{Determining the Initial List of Radionuclides}

Procedure WAC 2.02 (Rev. 4) stipulates that the characterization of each package of waste having a total activity greater than 2 nanocuries/gram must consider the potential presence of any radionuclide that meets any one of three criteria:

1. The radionuclide is identified in WAC 3.17 as being a Performance Assessment (PA) or Safety Authorization Basis (SAB) radionuclide for a specific Treatment, Storage or Disposal (TSD) facility (Reference 6). For purposes of this distribution, we will use those PA and $\mathrm{SAB}$ radionuclides for the EAV.

2. The radionuclide could be present in the waste with a relative activity greater than $1.0 \%$ of the total waste stream activity at the time of the characterization.

3. The radionuclide is a detectable transuranic or a fissile radionuclide.

The above criteria are hereafter referred to as "inclusion criteria."

Based on the three inclusion criteria and available process knowledge, the following list of 33 radionuclides (Table 3.1) will be considered when developing the radionuclide distribution of waste packages contaminated with sludge from Tanks 40,42 and 51 . 


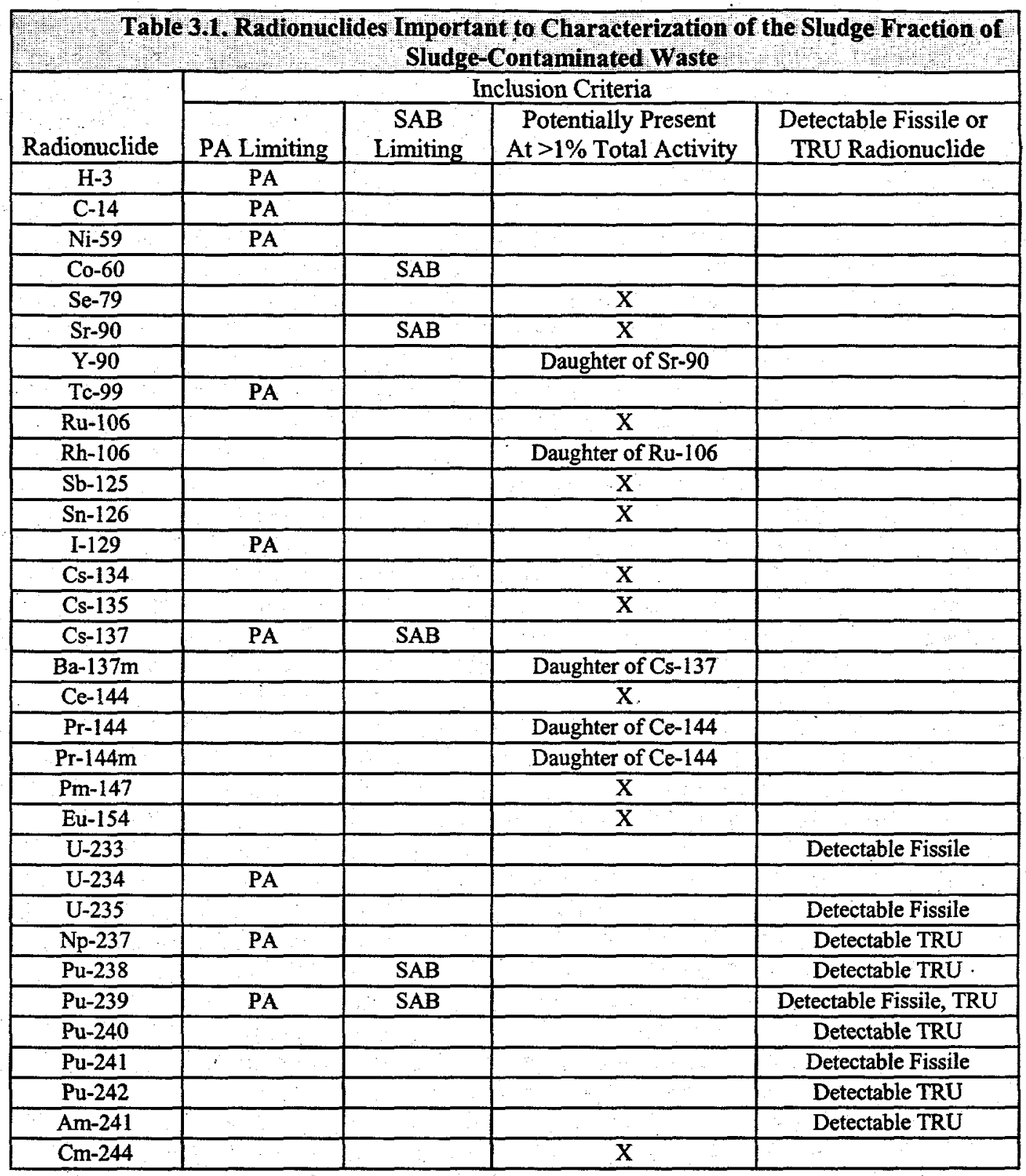

\subsection{Consolidating Sludge from Tanks 40,42 and 51}

WAC 2.02 (Rev. 4) allows for consolidation of waste streams when the following two criteria are met:

1. PA radionuclide scaling factors do not vary from the proposed data set scaling factor by more than a factor of 10 , and

2. The fractional activity of the predominant radionuclides (predominant radionuclides being those that make up $10 \%$ or greater of the activity) in each data set does not vary by more than a factor of 2 from the fractional activity of the same radionuclide in the proposed data set.

Historical data for tanks under consideration for consolidation are reproduced in Table 3.2. 


\begin{tabular}{|c|c|c|c|c|c|}
\hline \multicolumn{5}{|c|}{ Table 3.2, Tanks 40,42 and 51 Historical Data } \\
\hline $\begin{array}{c}\text { Tank } \\
\text { No. }\end{array}$ & $\begin{array}{c}\text { \% HM } \\
\text { HHW }\end{array}$ & $\begin{array}{c}\text { \% HM } \\
\text { LHW }\end{array}$ & $\begin{array}{c}\text { \% Purex } \\
\text { HHW }\end{array}$ & $\begin{array}{c}\text { \% Purex } \\
\text { LHW }\end{array}$ & Tank Use \\
\hline $\mathbf{4 0}$ & & 10 & & 90 & Extended Sludge Processing \\
$\mathbf{4 2}$ & 35 & 18 & & 47 & Extended Sludge Processing \\
$\mathbf{5 1}$ & 0.1 & 7 & & 92.9 & Extended Sludge Processing \\
& & & & & \\
Average & 11.7 & 11.7 & & 76.6 & \\
\hline
\end{tabular}

The tanks contain primarily Purex Low Heat Waste (LHW) aged 21-37 years, and are utilized for Extended Sludge Processing (ESP).

Significant process knowledge relating to what is present in the sludge fraction of these waste tanks exists. This process knowledge was used to develop scaling factors (to $\mathrm{Sr}-90$ ) for sludge fractions (Reference 1) in Tanks 40, 42 and 51. In addition, significant sludge sampling has been conducted on Tanks 42 and 51 (References 7 through 12). No sampling of Tank 40 sludge has been conducted. Tanks 42 and 51 are considered representative of Tank 40 sludge since the slurry in Tank 40 came primarily from the same Waste Receipt Tanks as Tank 51 waste. Tank 51 and Tank 42 have been blended.

Existing scaling factors for radionuclides identified in Section 3.1 were adjusted for decay and compared to scaling factors developed from both the available analytical data as well as data in WCTables (Reference 13). This analysis is documented in Attachments la andlb for Tanks 42 and 51, respectively. TRU radionuclides are present in analytical data by at least one order of magnitude greater than process knowledge predicts. Although analytical data indicates that some of the other radionuclides are present in amounts smaller than predicted by process knowledge, analytical data is considered most representative of the actual contents of sludge in these tanks. For this reason, only analytical data will be utilized to develop the radionuclide distribution for sludge in these tanks. Since the analytical data is in good agreement, the average of the analytical data for each isotope in tanks 42 and 51 will be used to develop scaling factors for each radionuclide within the tanks. (Attachments la and $1 b$ )

The set of isotope concentrations representative of Tanks 42 and 51 per the methodology above were next compared to each other to determine whether sludge-contaminated waste from these tanks met the two WAC criteria for consolidation.

First, the arithmetic mean concentration for each isotope under consideration was calculated. The concentrations for PA radionuclides for each waste stream were then compared to determine whether they were within an order of magnitude from the proposed data set, or the arithmetic mean set of concentrations. Within PA radionuclides, the greatest deviation from the mean was $\mathrm{Ni}-59$, which varied from the mean by $49 \%$. However, the variation observed is still well within a factor of 10 , the first criteria for consolidation. The mean set of scaling factors and the deviations from mean of the PA radionuclides are presented in Attachment 2.

The second criterion applies to predominant radionuclides only. There are two predominant radionuclides in this distribution, $\mathrm{Sr}-90$ and its daughter $\mathrm{Y}-90$. The fractional activities of Sr-90 and Y-90 vary only slightly within the distribution of sludge for each tank, ranging from 0.415 to 0.478 . The maximum variation from the proposed data set (the mean distribution) is $11.24 \%$ in Tank 51 sludge, which is well within a factor of 2 , the second criteria for consolidation. This is also documented in Attachment 2.

Based on the results of the comparison, both consolidation criteria are met, and the sludge fraction of sludge-contaminated waste from Tanks 40,42 and 51 may be consolidated. The arithmetic 
mean of scaling factors for tanks 42 and 51, previously developed in Attachment 2, will be used for the remainder of the development of the radionuclide distribution.

\subsection{Excluding Radionuclides from Consideration}

Under WAC 2.02 (Rev. 4) radionuclides that meet one of the inclusion criteria outlined in section 3.1 may be excluded from further consideration if one or more of the following conditions exist:

1. There is no reason to expect the radionuclide to be present in the waste stream.

2. Process knowledge shows that the PA radionuclide could not be present in the waste stream at concentrations greater than 1/100th of the Maximum Allowable Lower Limit of Detection (MALLD).

3. Historical representative data shows that a non-PA radionuclide is not present in the waste stream, or, if present, has a concentration below the MALLD.

The above criteria are hereafter referred to as "exclusion criteria."

In addition, review of those radionuclides that were initially included only because they were expected to be present at greater than $1 \%$ of total activity will be performed. If they are determined not to be present at greater than $1 \%$ of total activity, they will also be excluded.

Of the 33 radionuclides listed in Table 3.1 , one is excluded because it is not expected to be present. This same radionuclide, tritium, is also present at below 1/100 of the MALLD. No nonPA radionuclides are excluded based on the third criteria (non-PA isotopes present at less than the MALLD). Of the 15 radionuclides included because they were expected to be present at more than $1 \%$ of total activity, 13 are determined to be present at less than $1 \%$ of the total activity. Two of these, however, $\mathrm{Pm}-147$ and $\mathrm{Cm}-244$, are retained in the distribution since they are near $1 \%$ of total activity. Calculations supporting this determination are summarized in Attachment 3; the results of the determination are summarized in Attachment 4 and Table 3.3 below. 


\begin{tabular}{|c|c|c|c|c|}
\hline \multicolumn{5}{|c|}{$\begin{array}{r}\text { Table 3.3. Radionuclides Excluded from Consideration, Sludge Fraction } \\
\end{array}$} \\
\hline \multirow[b]{2}{*}{ Radionuclide } & \multicolumn{4}{|c|}{ Exclusion Criteria } \\
\hline & Not Expected & $\begin{array}{c}\text { PA Rads } \\
<.01 \text { of MALLD }\end{array}$ & $\begin{array}{l}\text { Non-PA } \\
<\text { MALLD } \\
\end{array}$ & $\begin{array}{l}\text { Present at } \\
<1 \% \text { (a) }\end{array}$ \\
\hline $\mathbf{H}-\mathbf{3}$ & $\mathbf{X}$ & $\mathbf{X}$ & & \\
\hline \multicolumn{5}{|l|}{ C-14 } \\
\hline \multicolumn{5}{|l|}{ Ni-59 } \\
\hline \multicolumn{5}{|l|}{ Co-60 } \\
\hline Se-79 & & & & $\mathrm{X}$ \\
\hline \multicolumn{5}{|l|}{$\mathrm{Sr}-90$} \\
\hline \multicolumn{5}{|l|}{ Y-90 } \\
\hline \multicolumn{5}{|l|}{ Tc-99 } \\
\hline Ru-106 & & & & $\mathrm{X}$ \\
\hline Rh-106 & & & & $\mathrm{X}$ \\
\hline $\mathrm{Sb}-125$ & & & & $\mathrm{X}$ \\
\hline $\mathrm{Sn}-126$ & & & & $\mathrm{X}$ \\
\hline \multicolumn{5}{|l|}{ I-129 } \\
\hline Cs-134 & & & & $\mathrm{X}$ \\
\hline Cs-135 & 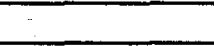 & & & $\mathrm{X}$ \\
\hline \multicolumn{5}{|l|}{ Cs-137 } \\
\hline \multicolumn{5}{|l|}{$\mathrm{Ba}-137 \mathrm{~m}$} \\
\hline $\mathrm{Ce}-144$ & & & & $X$ \\
\hline Pr-144 & $\because$ & & & $\mathrm{X}$ \\
\hline $\mathrm{Pr}-144 \mathrm{~m}$ & & & & $\mathrm{X}$ \\
\hline $\mathrm{Pm}-147$ & & & & $X(b)$ \\
\hline Eu-154 & & & & $\mathrm{X}$ \\
\hline $\mathrm{U}-233$ & $\cdots$ & & & \\
\hline \multicolumn{5}{|l|}{ U-234 } \\
\hline \multicolumn{5}{|l|}{ U-235 } \\
\hline \multicolumn{5}{|l|}{ Np-237 } \\
\hline \multicolumn{5}{|l|}{ Pu-238 } \\
\hline \multicolumn{5}{|l|}{ Pu-239 } \\
\hline \multicolumn{5}{|l|}{$\mathrm{Pu}-240$} \\
\hline \multicolumn{5}{|l|}{$\mathrm{Pu}-241$} \\
\hline \multicolumn{5}{|l|}{$\mathrm{Pu}-242$} \\
\hline \multicolumn{5}{|l|}{$\mathrm{Am}-241$} \\
\hline $\mathrm{Cm}-244$ & & & & $X(b)$ \\
\hline
\end{tabular}

(a) For those radionuclides included only because were thought to have been present at $>1 \%$ activity

(b) Retained in distribution because they are present at near $1 \%$ of total activity

Note: Bold = PA Rads 


\subsection{Development of the Sludge Fraction Distribution}

Thirty-three radionuclides were determined to be important to characterization of the sludge in Tanks 40,42 and 51. Twelve of these have been excluded per discussion in section 3.3 above, leaving 21 radionuclides to be quantified. Mean scaling factors developed previously to determine compatability of waste in the tanks have been utilized to create an isotopic distribution for this waste stream. The radionuclides, their corresponding scaling factors (to Sr-90) and fractional activity in the waste stream are summarized in Table 3.4 below. Summaries of inclusion and exclusion criteria as well as supporting calculations for the development of the activity distribution are provided in Attachment 4.

\begin{tabular}{|c|c|c|}
\hline $\begin{array}{r}\text { Table 3.4. Radionuclide Scaling Factors } \\
\text { and Distribution for Waste Sludge from Tanks 40, 42 and 51 }\end{array}$ \\
\hline Radionuclide & $\begin{array}{c}\text { Mean Scaling Factors } \\
\text { (Ci/Ci Sr-90) }\end{array}$ & $\begin{array}{c}\text { Mean Distribution, } \\
\text { Normalized (\%) }\end{array}$ \\
\hline $\mathrm{C}-14$ & $1.48 \mathrm{E}-06$ & $6.87 \mathrm{E}-05$ \\
\hline $\mathrm{Ni}-59$ & $1.47 \mathrm{E}-05$ & $6.84 \mathrm{E}-04$ \\
\hline $\mathrm{Co}-60$ & $3.73 \mathrm{E}-04$ & $1.73 \mathrm{E}-02$ \\
\hline Sr-90 & $1.00 \mathrm{E}+00$ & $4.65 \mathrm{E}+01$ \\
\hline $\mathrm{Y}-90$ & $1.00 \mathrm{E}+00$ & $4.65 \mathrm{E}+01$ \\
\hline Tc-99 & $7.06 \mathrm{E}-05$ & $3.28 \mathrm{E}-03$ \\
\hline $\mathrm{I}-129$ & $3.64 \mathrm{E}-07$ & $1.69 \mathrm{E}-05$ \\
\hline $\mathrm{Cs}-137$ & $3.64 \mathrm{E}-02$ & $1.69 \mathrm{E}+00$ \\
\hline $\mathrm{Ba}-137 \mathrm{~m}$ & $3.45 \mathrm{E}-02$ & $1.60 \mathrm{E}+00$ \\
\hline $\mathrm{Pm}-147$ & $1.92 \mathrm{E}-02$ & $8.93 \mathrm{E}-01$ \\
\hline $\mathrm{U}-233$ & $1.10 \mathrm{E}-05$ & $5.13 \mathrm{E}-04$ \\
\hline $\mathrm{U}-234$ & $8.93 \mathrm{E}-06$ & $4.15 \mathrm{E}-04$ \\
\hline $\mathrm{U}-235$ & $1.18 \mathrm{E}-07$ & $5.49 \mathrm{E}-06$ \\
\hline $\mathrm{Np}-237$ & $4.37 \mathrm{E}-06$ & $2.03 \mathrm{E}-04$ \\
\hline $\mathrm{Pu}-238$ & $3.78 \mathrm{E}-02$ & $1.76 \mathrm{E}+00$ \\
\hline $\mathrm{Pu}-239$ & $2.01 \mathrm{E}-03$ & $9.35 \mathrm{E}-02$ \\
\hline $\mathrm{Pu}-240$ & $6.41 \mathrm{E}-04$ & $2.98 \mathrm{E}-02$ \\
\hline $\mathrm{Pu}-241$ & $1.07 \mathrm{E}-02$ & $4.99 \mathrm{E}-01$ \\
\hline $\mathrm{Pu}-242$ & $9.56 \mathrm{E}-07$ & $4.44 \mathrm{E}-05$ \\
\hline $\mathrm{Am}-241$ & $2.40 \mathrm{E}-03$ & $1.12 \mathrm{E}-01$ \\
\hline $\mathrm{Cm}-244$ & $6.44 \mathrm{E}-03$ & $2.99 \mathrm{E}-01$ \\
\hline Total & & $1.00 \mathrm{E}+02$ \\
\hline
\end{tabular}

\subsection{Other WAC Criteria}

Procedure WAC 3.17, "Low Level Radioactive Waste Acceptance Criteria," (Reference 6) contains specific criteria that a waste box must meet in order to be accepted in specific TSD facilities. In this section, each of these criteria is compared to sludge slurry comprised of insoluble solids with the relative radionuclide abundance as defined in Table 3.4 above.

Analytical data from tanks 42 and 51 provide information to determine Curies/gram insoluble solids of each of the isotopes required for analysis of other WAC Criteria. The activity of the blended waste is calculated based on average $\mathrm{Ci} / \mathrm{g}$, along with a conservative value of $300 \mathrm{~g}$ insoluble solids in a liter of slurry. [The highest concentration of insoluble solids in sludge slurry to date has been measured at $258 \mathrm{~g} / \mathrm{L}$. (Reference 10)] The calculations are summarized in Table 3.5 , below. 


\begin{tabular}{|c|c|c|c|c|}
\hline \multicolumn{5}{|c|}{ Table 3.5 Calculation of Blended Activities for Waste Stream 40/42/51 } \\
\hline Isotope & $\begin{array}{c}\text { Ci/g insoluble } \\
\text { solids, Tank 42 }\end{array}$ & $\begin{array}{c}\text { Ci/g insoluble } \\
\text { solids, Tank 51 }\end{array}$ & $\begin{array}{c}\text { Average Ci/g } \\
\text { insoluble solids }\end{array}$ & $\begin{array}{c}\text { Average Ci/gallon } \\
\text { sludge slurry }\end{array}$ \\
\hline H-3 & $0.00 \mathrm{E}+00$ & $0.00 \mathrm{E}+00$ & $0.00 \mathrm{E}+00$ & $0.00 \mathrm{E}+00$ \\
C-14 & $5.00 \mathrm{E}-09$ & $0.00 \mathrm{E}+00$ & $5.00 \mathrm{E}-09$ & $5.68 \mathrm{E}-06$ \\
Ni-59 & $7.41 \mathrm{E}-08$ & $2.54 \mathrm{E}-08$ & $4.98 \mathrm{E}-08$ & $5.65 \mathrm{E}-05$ \\
Co-60 & $1.24 \mathrm{E}-06$ & $1.28 \mathrm{E}-06$ & $1.26 \mathrm{E}-06$ & $1.43 \mathrm{E}-03$ \\
Sr-90* & $5.87 \mathrm{E}-03$ & $8.95 \mathrm{E}-04$ & $3.38 \mathrm{E}-03$ & $3.84 \mathrm{E}+00$ \\
Tc-99 & $1.89 \mathrm{E}-07$ & $2.88 \mathrm{E}-07$ & $2.39 \mathrm{E}-07$ & $2.71 \mathrm{E}-04$ \\
I-129 & $1.23 \mathrm{E}-09$ & $0.00 \mathrm{E}+00$ & $1.23 \mathrm{E}-09$ & $1.40 \mathrm{E}-06$ \\
Cs-137 & $1.82 \mathrm{E}-04$ & $6.54 \mathrm{E}-05$ & $1.24 \mathrm{E}-04$ & $1.40 \mathrm{E}-01$ \\
Ba-137m & $1.73 \mathrm{E}-04$ & $6.18 \mathrm{E}-05$ & $1.17 \mathrm{E}-04$ & $1.33 \mathrm{E}-01$ \\
Pm-147 & $0.00 \mathrm{E}+00$ & $0.00 \mathrm{E}+00$ & $0.00 \mathrm{E}+00$ & $0.00 \mathrm{E}+00$ \\
U-233 & $4.26 \mathrm{E}-08$ & $3.24 \mathrm{E}-08$ & $3.75 \mathrm{E}-08$ & $4.26 \mathrm{E}-05$ \\
U-234 & $2.93 \mathrm{E}-08$ & $3.14 \mathrm{E}-08$ & $3.03 \mathrm{E}-08$ & $3.44 \mathrm{E}-05$ \\
U-235 & $3.71 \mathrm{E}-10$ & $4.32 \mathrm{E}-10$ & $4.01 \mathrm{E}-10$ & $4.56 \mathrm{E}-07$ \\
Np-237 & $1.51 \mathrm{E}-08$ & $1.85 \mathrm{E}-08$ & $1.68 \mathrm{E}-08$ & $1.90 \mathrm{E}-05$ \\
Pu-238 & $1.09 \mathrm{E}-04$ & $1.47 \mathrm{E}-04$ & $1.28 \mathrm{E}-04$ & $1.45 \mathrm{E}-01$ \\
Pu-239 & $5.35 \mathrm{E}-06$ & $8.26 \mathrm{E}-06$ & $6.80 \mathrm{E}-06$ & $7.72 \mathrm{E}-03$ \\
Pu-240 & $1.82 \mathrm{E}-06$ & $2.47 \mathrm{E}-06$ & $2.15 \mathrm{E}-06$ & $2.44 \mathrm{E}-03$ \\
Pu-241 & $4.19 \mathrm{E}-05$ & $3.07 \mathrm{E}-05$ & $3.63 \mathrm{E}-05$ & $4.12 \mathrm{E}-02$ \\
Pu-242 & $3.78 \mathrm{E}-09$ & $2.51 \mathrm{E}-09$ & $3.15 \mathrm{E}-09$ & $3.57 \mathrm{E}-06$ \\
Am-241 & $7.78 \mathrm{E}-06$ & $8.48 \mathrm{E}-06$ & $8.13 \mathrm{E}-06$ & $9.24 \mathrm{E}-03$ \\
Cm-244 & $6.19 \mathrm{E}-06$ & $3.74 \mathrm{E}-05$ & $2.18 \mathrm{E}-05$ & $2.47 \mathrm{E}-02$ \\
& & & & \\
Total & $1.23 \mathrm{E}-02$ & $2.15 \mathrm{E}-03$ & $7.23 \mathrm{E}-03$ & $8.21 \mathrm{E}+00$ \\
\hline
\end{tabular}

*Note: Sr-90 exists in equilibrium with its daughter Y-90

The activity of the blended waste stream is $8.21 \mathrm{Ci} /$ gallon sludge slurry. The weighted average activity of individual radionuclides will be used in comparisons to other WAC criteria in the following sections.

\subsubsection{Comparison to Package Guidelines}

Most sludge-contaminated waste will be disposed of in the E-Area Vaults. Administrative Waste Package Radiological Concentration Guidelines apply to waste disposed of in the EAV. The guidelines applicable to the Low Activity Waste Vault (LAWV), that portion of the EAV reserved for Low Activity Waste (LAW) will be used for comparison since they are the most restrictive of the EAV facilities. LAW is defined as waste that will produce less than or equal to $200 \mathrm{mR} / \mathrm{hr}$ at $5 \mathrm{~cm}$ from an unshielded final disposal container. Radionuclides present in this waste stream and their corresponding LAWV limits are summarized in Table 3.6 below.

\begin{tabular}{|c|c|c|c|c|}
\hline & \multicolumn{5}{|c|}{$\begin{array}{c}\text { Table 3.6 Comparison of Sludge-Contaminated Waste } \\
\text { to LAWV Limits }\end{array}$} \\
\hline Radionuclide & $\begin{array}{c}\text { LAWV Limit } \\
\text { (Ci/ft3) }\end{array}$ & $\begin{array}{c}\text { LAWV Limit } \\
\text { (Ci/B-25) }\end{array}$ & $\begin{array}{c}\text { Sludge Slurry } \\
\text { (Ci/gal) }\end{array}$ & $\begin{array}{c}\text { Gal Sludge in B-25 to } \\
\text { Reach LAWV Limit }\end{array}$ \\
\hline Sr-90 & $\mathrm{A}$ & $\mathrm{B}=\mathrm{A}^{* 90 \mathrm{ft} 3 / \mathrm{B}-25}$ & $\mathrm{C}$ & $\mathrm{D}=\mathrm{C} / \mathrm{B}$ \\
\hline $\mathrm{Tc}-99$ & $2.4 \mathrm{E}+00$ & $2.16 \mathrm{E}+02$ & $3.84 \mathrm{E}+00$ & $5.62 \mathrm{E}+01$ \\
\hline $\mathrm{I}-129$ & $1.90 \mathrm{E}-05$ & $1.71 \mathrm{E}-03$ & $2.71 \mathrm{E}-04$ & $6.31 \mathrm{E}+00$ \\
\hline $\mathrm{Cs}-137$ & $9.2 \mathrm{E}-09$ & $8.28 \mathrm{E}-07$ & $1.40 \mathrm{E}-06$ & $5.92 \mathrm{E}-01$ \\
\hline Pu-238 & $8.4 \mathrm{E}-02$ & $7.56 \mathrm{E}+00$ & $1.40 \mathrm{E}-01$ & $5.39 \mathrm{E}+01$ \\
\hline & $6.9 \mathrm{E}-03$ & $6.21 \mathrm{E}-01$ & $1.45 \mathrm{E}-01$ & $4.27 \mathrm{E}+00$ \\
\hline
\end{tabular}


The most limiting isotope is $\mathrm{I}-129$, which requires 0.6 gallons of sludge slurry in a B-25 to meet the LAWV Limit. 0.6 gallons of sludge slurry would be equivalent to nearly $5 \mathrm{Ci}$ in a B-25, 0.98 $\mathrm{Ci}$ of which are transuranics. Any waste box containing $0.98 \mathrm{Ci}$ (or $9.8 \mathrm{E}+8 \mathrm{nCi}$ ) in sludge slurry must contain $9.8 \mathrm{E}+6$ grams (or 2,150 lbs.) or more of waste (out of the 5,000-lb. limit) in order to be within the TRU limit of $100 \mathrm{nCi} / \mathrm{g}$ transuranics. A box with less than $2,150 \mathrm{lbs}$. of waste and 0.6 gallons or more of sludge slurry will fail the TRU limits. In practice, very few waste boxes fail TRU limits due to their relatively low curie content. Any box containing TRU waste will, upon entry into WITS, be flagged as TRU and not be sent to the LAWV.

\subsubsection{Sum of Fractions Calculation}

For acceptance of waste packages sent to the LAWV, the radiological content of the waste package must be compared to the administrative guidelines and shown to satisfy the sum-offractions criteria where:

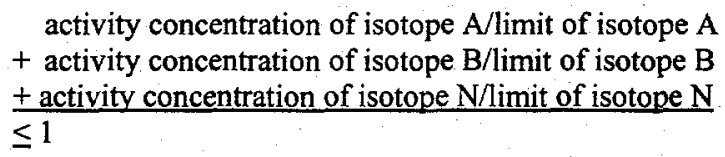

Table 3.7 below calculates the maximum concentration of sludge slurry on sludge-contaminated waste in order for the sum-of-the-fractions criteria to be met. The criteria are met for a maximum of 7.0E-04 ft3 (or 0.47 gallons) of sludge slurry per B-25. This is equivalent to $3.87 \mathrm{Ci}$ of sludge solids in a B-25, or $0.078 \mathrm{Ci}$ of transuranics for this waste stream. Any waste box containing $0.078 \mathrm{Ci}$ (or $7.8 \mathrm{E}+07 \mathrm{nCi}$ ) in sludge slurry must contain $7.8 \mathrm{E}+05 \mathrm{~g}$ (or 1,700 lbs.) or more of waste (out of the 5,000-lb. limit) in order to be within the TRU limit of $100 \mathrm{nCi} / \mathrm{g}$ transuranics. A box with less than $1,700 \mathrm{lbs}$. of waste and 0.47 gallons or more of sludge slurry will fail the TRU limits. In practice, very few waste boxes fail TRU limits. Any such box will, upon entry into WITS, be flagged as TRU and not be sent to the LAWV.

\begin{tabular}{|c|c|c|c|c|c|c|}
\hline \multicolumn{2}{|c|}{ Table 3.7 Sum-of-Fractions for Sludge Fraction of Sludge-Contaminated Waste } \\
\hline Isotope & $\begin{array}{c}\text { Ci/gallon } \\
\text { Sludge slurry }\end{array}$ & $\begin{array}{c}\text { Ci/ft3 } \\
\text { Sludge }\end{array}$ & $\begin{array}{c}\text { ft3 Sludge/ } \\
\text { ft3 Waste }\end{array}$ & $\begin{array}{c}\text { Ci/ft3 } \\
\text { Waste }\end{array}$ & $\begin{array}{c}\text { LWWV Limit } \\
\text { (Cift3) }\end{array}$ & Fraction \\
\hline & $\mathrm{A}$ & $\mathrm{B}=\mathrm{A}^{*} 7.48$ & $\mathrm{C}$ & $\mathrm{D}=\mathrm{B}^{*} \mathrm{C}$ & $\mathrm{E}$ & $=\mathrm{D} / \mathrm{E}$ \\
\hline $\mathrm{Sr}-90$ & $3.84 \mathrm{E}+00$ & $2.87 \mathrm{E}+01$ & $7.00 \mathrm{E}-04$ & $2.01 \mathrm{E}-02$ & $2.40 \mathrm{E}+00$ & $8.38 \mathrm{E}-03$ \\
\hline $\mathrm{Tc}-99$ & $2.71 \mathrm{E}-04$ & $2.03 \mathrm{E}-03$ & $7.00 \mathrm{E}-04$ & $1.42 \mathrm{E}-06$ & $1.90 \mathrm{E}-05$ & $7.47 \mathrm{E}-02$ \\
\hline $\mathrm{I}-129$ & $1.40 \mathrm{E}-06$ & $1.05 \mathrm{E}-05$ & $7.00 \mathrm{E}-04$ & $7.32 \mathrm{E}-09$ & $9.20 \mathrm{E}-09$ & $7.96 \mathrm{E}-01$ \\
\hline $\mathrm{Cs}-137$ & $1.40 \mathrm{E}-01$ & $1.05 \mathrm{E}+00$ & $7.00 \mathrm{E}-04$ & $7.35 \mathrm{E}-04$ & $8.40 \mathrm{E}-02$ & $8.75 \mathrm{E}-03$ \\
\hline $\mathrm{Pu}-238$ & $1.45 \mathrm{E}-01$ & $1.09 \mathrm{E}+00$ & $7.00 \mathrm{E}-04$ & $7.62 \mathrm{E}-04$ & $6.90 \mathrm{E}-03$ & $1.10 \mathrm{E}-01$ \\
\hline \multicolumn{7}{|c|}{ Sum of Fractions } \\
\hline
\end{tabular}

\subsubsection{Nuclear Criticality Safety Criteria}

Sludge-contaminated LLW contains an insignificant quantity of fissionable material to impact nuclear criticality criteria. Table 3.8, below, shows the maximum quantity of sludge that could be placed in a B-25 prior to exceeding the 50-g Fissile Gram Equivalent (FGE) U-235 limit. This is equivalent to 118 gallons of sludge slurry, and over 975 curies in a B-25, significantly greater than the TRU waste limit. Any such box will not be sent to the LAWV for disposal, therefore protecting this requirement. 


\begin{tabular}{|c|c|c|c|c|c|c|c|}
\hline & & $\begin{array}{l}\text { Table } 3 \\
\text { for Sludge }\end{array}$ & $\begin{array}{l}\text { 3.8. Calcul } \\
\text { Fraction of }\end{array}$ & $\begin{array}{l}\text { tion of FGE } \\
\text { Sludge-Con }\end{array}$ & $\begin{array}{l}\text { Equivalent } \\
\text { taminated }\end{array}$ & Naste & \\
\hline $\begin{array}{l}\text { Radio- } \\
\text { nuclide }\end{array}$ & $\begin{array}{c}\text { Activity } \\
\text { in } \\
\text { blended } \\
\text { waste } \\
\text { (Ci/gal) }\end{array}$ & \begin{tabular}{|c|} 
Maximum \\
Gallons of \\
sludge in a \\
B-25 to \\
meet FGE \\
Equivalent
\end{tabular} & \begin{tabular}{|c} 
Maximum \\
Curies \\
Sludge in \\
a B-25
\end{tabular} & $\begin{array}{c}\text { Specific } \\
\text { Activity } \\
\text { (Ci/g) }\end{array}$ & $\begin{array}{c}\text { Maximum } \\
\text { Mass } \\
\text { (grams) in } \\
\text { a B-25 }\end{array}$ & $\begin{array}{c}\text { Equivalence } \\
\text { Factor (from } \\
\text { WSRC 1S } \\
\text { Manual) }\end{array}$ & $\begin{array}{c}\text { FGE } \\
\text { U-235 (g) }\end{array}$ \\
\hline & A & $\mathbf{B}$ & $C=A * B$ & $\mathrm{D}$ & $\mathrm{E}=\mathrm{C} / \mathrm{D}$ & $\mathrm{F}$ & $G=E * F$ \\
\hline U-233 & $4.26 \mathrm{E}-05$ & 118.8 & $5.06 \mathrm{E}-03$ & $9.648 \mathrm{E}-03$ & $5.24 \mathrm{E}-01$ & 1.4 & $7.34 \mathrm{E}-01$ \\
\hline U-235 & $4.56 \mathrm{E}-07$ & 118.8 & $5.42 \mathrm{E}-05$ & $2.16 \mathrm{E}-06$ & $2.51 \mathrm{E}+01$ & 1.0 & $2.51 \mathrm{E}+01$ \\
\hline Pu-239 & $7.72 \mathrm{E}-03$ & 118.8 & $9.17 \mathrm{E}-01$ & $6.2 \mathrm{E}-02$ & $1.48 \mathrm{E}+01$ & 1.6 & $2.36 \mathrm{E}+01$ \\
\hline $\mathrm{Pu}-241$ & $4.12 \mathrm{E}-02$ & 118.8 & $4.89 \mathrm{E}+00$ & $1.034 \mathrm{E}+02$ & $4.73 \mathrm{E}-02$ & 3.5 & $1.66 \mathrm{E}-01$ \\
\hline Am-242m & 0 & 118.8 & 0 & $9.717 \mathrm{E}+00$ & 0 & 54.0 & 0 \\
\hline $\mathrm{Cm}-243$ & 0 & 118.8 & 0 & $5.253 \mathrm{E}+01$ & 0 & 7.8 & 0 \\
\hline $\mathrm{Cm}-245$ & 0 & 118.8 & 0 & $1.716 \mathrm{E}-01$ & 0 & 24.0 & 0 \\
\hline $\mathrm{Cm}-247$ & 0 & 118.8 & 0 & $9.396 \mathrm{E}-05$ & 0 & 1.6 & 0 \\
\hline Cf-249 & 0 & 118.8 & 0 & $4.078 \mathrm{E}+00$ & 0 & 70.0 & 0 \\
\hline Cf-251 & 0 & 118.8 & 0 & $1.582 \mathrm{E}+00$ & 0 & 140.0 & 0 \\
\hline
\end{tabular}

\subsubsection{Class C Waste Determination}

The sludge fraction of sludge-contaminated LLW disposed at the LAWV does not exceed Class C waste criteria. Table 3.9 includes the Class $C$ radionuclide criteria (10 CFR 61.55, Table 1) along with the LAWV and ILV (Intermediate Level Vault) radionuclide criteria. The data indicates that the current LAWV and ILV radionuclide criteria are much more restrictive than the 10 CFR 61 criteria for Class $\mathrm{C}$ waste.

\begin{tabular}{|c|c|c|c|}
\hline Table 3.9.Class C Waste Analysis, Sludge Fraction of Sludge-Contaminated Waste \\
\hline $\begin{array}{c}\text { Radionuclide } \\
\text { Class C } \\
\text { (Ci/ft3) }\end{array}$ & $\begin{array}{c}\text { WAC 3.17 for } \\
\text { LAWV (Cift3) }\end{array}$ & WAC 3.17 for IUV (Cift3) \\
\hline C-14 & $2.27 \mathrm{E}-01$ & $3.7 \mathrm{E}-04$ & $4.7 \mathrm{E}-04$ \\
\hline Ni-59 & $6.23 \mathrm{E}+00$ & $7.0 \mathrm{E}-03$ & $8.3 \mathrm{E}-02$ \\
\hline Tc-99 & $8.50 \mathrm{E}-02$ & $1.9 \mathrm{E}-05$ & $9.2 \mathrm{E}-05$ \\
\hline $\mathrm{I}-129$ & $2.27 \mathrm{E}-03$ & $9.2 \mathrm{E}-09$ & $2.4 \mathrm{E}-08$ \\
\hline & $\begin{array}{c}\text { Class C } \\
\text { (nanocurie/g) }\end{array}$ & & \\
\hline Alpha & $1.00 \mathrm{E}+02$ & See discussion below & \\
\hline Pu-241 & $3.50 \mathrm{E}+03$ & See discussion below & \\
\hline Cm-242 & $2.00 \mathrm{E}+04$ & See discussion below & \\
\hline
\end{tabular}

Alpha - The alpha criteria is identical to the restriction on the disposal of TRU waste in the waste acceptance criteria.

Pu-241 - Pu-241 can be as high as $21 \%$ of total plutonium activity. Based on the Class C criteria, this would allow 16,500 nanocuries/gram of total plutonium before the criteria would be exceeded. Subtracting the Pu-241 activity results in 13,000 nanocuries/gram of alpha-emitting plutonium isotopes. This exceeds the criteria for TRU waste and would not be allowed.

Cm-242 - Cm-242 is not expected in HLW sludge based on knowledge of the processes that have generated the waste and its 162.5-day half-life. 


\subsection{Documentation of the Sludge Fraction Distribution}

Low level waste stream form WPT-00002-51, included as Attachment 5, documents the distribution from Tanks 40,42 and 51. For those packages determined to contain sufficient sludge to be determined mixed and/or transuranic, appropriate waste stream forms will be provided for each package.

\subsection{Supernate Fraction of Sludge-Contaminated Waste}

\subsection{Radionuclide Distribution}

The radionuclide distribution for the supernate fraction of sludge-contaminated waste has been previously determined and documented. "HLW Supernate Radionuclide Characterization," WSRC-TR-94-0290, Rev. 3, April 19, 1999, identifies 14 radionuclides present in supernate waste. This waste stream represents a single, comprehensive and conservative characterization/certification for all supernate in both F- and H-Areas. The waste stream consists primarily of Cs- 137 and its daughter Ba- $137 \mathrm{~m}$, which together comprise $97 \%$ of the total activity in supernate. The fourteen isotopes determined to be present in supernate waste, their relative activity and scaling factors (to Cs-137) for this waste stream are reproduced in Table 4.1 below.

\begin{tabular}{|c|c|c|}
\hline $\begin{array}{c}\text { Table 4.1. Validated Radionuclide Distribution } \\
\text { and Scaling Factors for HLW Supernate }\end{array}$ \\
\hline Radionuclide & $\begin{array}{c}\text { Normalized } \\
\text { Distribution (\%) }\end{array}$ & $\begin{array}{c}\text { Scaling Factors } \\
\text { (Ci/Ci Cs-137) }\end{array}$ \\
\hline H-3 & $2.0 \mathrm{E}-01$ & $4.0 \mathrm{E}-03$ \\
\hline Co-60 & $1.7 \mathrm{E}+00$ & $3.4 \mathrm{E}-02$ \\
\hline Sr-90 & $4.7 \mathrm{E}-02$ & $9.3 \mathrm{E}-04$ \\
\hline Tc-99 & $9.1 \mathrm{E}-03$ & $1.8 \mathrm{E}-04$ \\
\hline $\mathrm{I}-129$ & $1.1 \mathrm{E}-05$ & $2.1 \mathrm{E}-07$ \\
\hline Cs-137 & $5.0 \mathrm{E}+01$ & $1.0 \mathrm{E}+00$ \\
\hline Ba-137m & $4.7 \mathrm{E}+01$ & $9.4 \mathrm{E}-01$ \\
\hline U-233 & $2.6 \mathrm{E}-04$ & $5.2 \mathrm{E}-06$ \\
\hline U-234 & $7.1 \mathrm{E}-05$ & $1.4 \mathrm{E}-06$ \\
\hline Pu-238 & $2.5 \mathrm{E}-01$ & $5.0 \mathrm{E}-03$ \\
\hline Pu-239 & $2.9 \mathrm{E}-03$ & $5.9 \mathrm{E}-05$ \\
\hline Pu-240 & $1.3 \mathrm{E}-03$ & $2.6 \mathrm{E}-05$ \\
\hline Pu-241 & $1.9 \mathrm{E}-01$ & $3.8 \mathrm{E}-03$ \\
\hline Am-241 & $1.8 \mathrm{E}-02$ & $3.5 \mathrm{E}-04$ \\
\hline Total & $\mathbf{1 . 0 E}+02$ & \\
\hline
\end{tabular}




\subsection{Other WAC Criteria}

Comparison of supernate waste to other WAC requirements has been performed previously (Reference 5). The following determinations were made for supernate waste:

- $\quad \mathrm{A} \mathrm{B}-25$ container $90 \%$ full ( $81 \mathrm{ft} 3$ waste) can contain up to 0.36 gallons of supernate $(1.8$ Ci Cs-137), approximately 50-200 times the estimate of supernate expected in a typical B-25 before it is expected to exceed the LAWV Administrative Waste Package Radiological Concentration Guidelines

- Supernate waste passes the sum of fractions calculation

- Supernate waste contains an insignificant quantity of fissionable material to impact nuclear criticality criteria

- Supernate waste does not exceed Class $\mathrm{C}$ waste criteria

4.3 Documentation of Supernate Fraction Distribution

Low Level waste stream form WPT-00001, included in Attachment 6, will be used to document the supernate fraction distribution of sludge waste.

\subsection{Quantification}

\subsection{Quantification of Sludge and Supernate Fractions}

Quantification of radionuclides in sludge-contaminated waste requires quantification of both the supernate and sludge fractions in each waste cut. Independent quantification of Sr-90, indicative of the sludge fraction, and Cs-137, indicative of the supernate fraction, is key to accurate characterization of sludge-contaminated waste. Both the sludge and supernate fractions and their scaling ratios to Sr-90 and Cs-137, respectively, are reproduced in Attachment 7.

Scaling factors for the sludge fraction are tied to Sr-90. Although Sr-90 is present in the supernate fraction, it comprises less than $1 \%$ of total activity in the supernate fraction. For this reason, all Sr90 identified in the sludge-contaminated waste will be attributed to the sludge fraction. Scaling ratios developed for the sludge fraction will be applied to the Sr-90 identified in sludgecontaminated waste.

Scaling factors for the supernate fraction are tied to Cs-137. Although Cs-137 is present in the sludge fraction, it comprises only about $5 \%$ of total activity in the sludge fraction. For this reason, all Cs-137 identified in sludge-contaminated waste will be attributed to the supernate fraction. Scaling ratios developed for supernate will be applied to the Cs-137 identified in sludgecontaminated waste.

The two fractions of sludge-contaminated waste will be manifested separately. The dose of Cs137 and Sr-90 will be entered into two separate waste streams in WITS, representing the sludge and supernate fractions, respectively, which will calculate curies attributed to each radionuclide identified in the respective distributions. The two waste streams will be combined in WITS to create a single manifest.

\subsection{Quantification of Job Control Waste and Other Compactable Sludge-Contaminated Waste}

The relative ease with which gamma radiation from Cs- 137 is detected makes estimation of the curie content of the supernate fraction of waste straightforward. Dose-to-curie methodologies for 
quantification of Cs-137 on waste containers have been developed and are currently in use (References 14 and 15).

Sr-90, a low-energy beta emitter, is not easily measured. Although a Beta Screening Tool (BST) has been developed as an improved alternative method for providing a dose associated with $\mathrm{Sr}-90$ (Reference 16), the BST methodology has not yet been implemented for waste quantification purposes. Until such time as the BST is field implemented, the actual quantity of Sr-90 present in the sludge fraction must be estimated by some other means.

The most conservative approach in quantification of a waste cut is to assume that all measured Cs137 is attributed to both supernate and sludge fractions. For the sludge fraction, the known Sr-90 to Cs-137 ratio is utilized to estimate the maximum Sr-90 that could be present on the waste cut. This approach results in double-manifesting of the Cs-137, over-manifesting of virtually all of the remaining radionuclides, and significantly over-estimating the sludge fraction (recall that Cs-137 and its daughter $\mathrm{Ba}-137 \mathrm{~m}$ comprises over $97 \%$ of the activity in supernate, while it comprises less than $5 \%$ of the activity in sludge).

It is preferable, therefore, to determine an appropriate split of the measured Cs-137 that can be attributed to the supernate and sludge fractions. In determining the appropriate split between these fractions, one must consider the effects of overestimating one fraction or the other. Overestimating the sludge fraction will result in

- under-manifesting of radionuclides attributed to supernate only (in this waste stream, the only radionuclide fitting this description is tritium, a PA radionuclide, present at $0.2 \%$ of total supernate activity), and

- over-manifesting of transuranics (a higher level of transuranics are present in sludge).

Over-estimating the supernate fraction will result in under-manifesting of radionuclides present in the sludge fraction only. In this waste stream, these include C-14, Ni-59, Y-90, Pm-147, Eu-154, $\mathrm{U}-235$ and $\mathrm{Np}-237$. $\mathrm{C}-14, \mathrm{Ni}-59$ and $\mathrm{Np}-237$ are PA radionuclides.

For our purposes, we will consider contamination of waste with settled sludge, thereby maximizing the sludge fraction, to be the most conservative estimate on which to base a split of Cs-137. This is based on the prevailing consideration that sludge contains more transuranics than supernate. Available analytical data to date have measured the maximum concentration of insoluble solids of approximately 258 grams/liter in settled sludge slurry (Reference 7). Given the radionuclide distributions for the sludge and supernate fractions in this report, one can conservatively bound the sludge to supernate ratio based on the maximum concentration of insoluble solids in settled sludge of 300 grams/liter.

For a box of compactable waste, the quantification may be performed as follows:

Given: Cs-137 is present in Tank 40/42/51 unwashed supernate at $7.8 \mu \mathrm{Ci} / \mathrm{ml}(\operatorname{Ref} 10)$; there are $0.94 \mathrm{~L}$ supernate/L slurry (Attachment 1 ) and Cs-137 is present in tank 40/42/51 sludge at an average of $1.24 \mathrm{E}-04 \mathrm{Ci} / \mathrm{g}$ insoluble solids (Table 3.5). For one liter of slurry, there are $(7.8$ $\mu \mathrm{Ci} / \mathrm{ml}$ supernate $* 0.94 \mathrm{~L}$ supernate $/ \mathrm{L}$ slurry $\doteq$ ) $7.3 \mathrm{E}-03 \mathrm{Ci} \mathrm{Cs}-137$ attributable to supernate. For this same liter of slurry, there are $(300 \mathrm{~g}$ insoluble solids/L slurry * $1.24 \mathrm{E}-04 \mathrm{Ci} / \mathrm{g}$ insoluble solids $\Rightarrow 1.96 \mathrm{E}-02 \mathrm{Ci} \mathrm{Cs}-137$ attributable to insoluble sludge solids. In this liter of slurry, there are a total of $(0.0196+0.0073 \Rightarrow) 0.027 \mathrm{Ci} \mathrm{Cs}-137,27.2 \%$ of which are found in the supernate fraction and $72.8 \%$ found in the sludge fraction. 
Using this split of the total Cs- 137 present on the waste box, one can calculate the Cs- 137 curies in the supernate fraction ( $27.2 \%$ of the total) and sludge fraction $(72.8 \%$ of the total). Using the ratio of Sr-90 to Cs-137 in the sludge fraction from Attachment $7(1.0 / 0.0364)$, we can determine the total $\mathrm{Ci} \mathrm{Sr}-90$ in the sludge fraction. The relative abundance of radionuclides in both the supernate and sludge fractions can then be calculated from their scaling factors to Cs-137 and Sr90, respectively (see Attachment 7).

Deviation from this conservative approach may be considered on a case-by-case basis. Such other considerations may include, but are not limited to, one or more of the following:

- maintenance of a well-stirred tank that would result in contamination of waste with sludge slurry rather than settled sludge

- origin of the waste material, which may limit its exposure to sludge contamination

- analytical or survey data which may be indicative of a higher supernate fraction.

When application of an alternative approach is to be utilized, the technical basis must be documented.

\subsection{Quantification of Non-Compactable Sludge-Contaminated Waste}

Estimation of the quantity of Cs-137 present on non-compactable waste (e.g., equipment) is performed on a case-by-case basis. This is done by individual Dose-to-Curie runs, which take into account the specific geometry of the waste. (Reference 17). These are performed by Solid Waste Management Department personnel.

Application of BST methodology to non-compactable waste to determine the amount of Sr-90 present is not appropriate since the waste itself shields beta radiation and would therefore result in unrealistically low measured values. Estimation of Sr-90 present in cuts of non-compactable waste will be performed by estimation of the amount of Cs-137 attributed to the sludge fraction in combination with the known relationship between Sr-90 and Cs-137. This will be performed in the same method outlined in section 5.2 for compactable waste.

Additional considerations for deviation from the conservative approach identified in section 5.2 (contamination of waste with settled sludge) for non-compactable waste include

- washing or other processing of the waste after its removal from the waste tank.

6.0 Periodic Review and Validation

Provisions of Procedure WAC 2.02 (Rev. 4) require generators of routine wastes, including sludge-contaminated waste, to review each waste stream at least annually and validate radionuclide distributions at least every two years.

In addition to the annual review, review of the radionuclide distribution for sludge in tanks 40,42 and 51 will be conducted on a more frequent basis if required to address process changes that may affect the distribution. These changes consist of anything that would cause the mean radionuclide distribution to change to the degree that the difference between the distribution documented in this report and the revised distribution exceeds the consolidation criteria identified in section 3.2 of this report. These changes may include, but are not limited to, the following:

- Addition of sludge waste into tanks 40,42 , or 51 from a waste tank other than these tanks

- Processing conducted in tanks 40,42 or 51 that may result in a change in the distribution 


\subsection{References}

1 D'Entremont, P. D., "HLW Sludge Characterization in Support of Low Level Waste Certification (U)," WSRC-TR-94-0579, Rev. 1., December 15, 1994.

2. Georgeton, G. K. and J. R. Hester, "Characterization of Radionuclides in HLW Sludge Based on Isotopic Distribution in Irradiated Assemblies (U)," WSRC-TR94-0562, Rev. 1., January 27, 1995.

3 M:IWastelReportsiWSRCTR.93425b.xls, "Waste Transfers and Additions Database."

4 Procedure WAC 2.02, Low Level Waste Characterization Requirements, WSRC 1S Savannah River Site Waste Acceptance Criteria Manual, Rev. 4, Savannah River Site, June 30, 1999.

5 E. T. Ketusky and R. F. O'Bryant, "HLW Supernate Radionuclide Characterization," WSRC-TR-94-0290, Rev. 3, April 19, 1999.

6 Procedure WAC 3.17, Low Level Waste Acceptance Criteria, WSRC is Savannah River Site Waste Acceptance Manual, Rev. 2, Savannah River Site, June 10, 1999.

7 M. S. Hay and N. E. Bibler, "Characterization and Sludge Washing Studies of Tank 42H Sludge (U)," WSRC-RP-94-730, July 27, 1994.

8 WSRC-RP-0436, T. L. Fellinger and N. E. Bibler, "Characterization of and Waste Acceptance Radionuclides to be Reported for DWPF Macro Batch 2 (ESP 215ESP-221) (U),"June 21, 1999.

9 WSRC-RP-98-0406, M. S. Hay and N. E. Bibler, Characterization and Decant of Tank 42H Sludge Sample ESP-200, 6/12/98.

10 WSRC-RP-95-1003, M. S. Hay and N.E. Bibler, The Characterization and Centrifuge-Settled Washing of a Tank $51 \mathrm{H}$ Sludge Sample Obtained in October 1995(U), 11/25/95

11 WSRC-TR-95-0487, N. E. Bibler and O. B. Hodoh, Calculating Waste Acceptance Radionuclides in DWPF Tank 51 Sludge Only Glass, Rev. 1, 10/15/96

12 WSRC-TR-94-0505, N. E. Bibler, W. F. Kinard, R. A. Dewberry and C. J. Coleman, A Method for the Determination of Waste Acceptance Radionuclides in DWPF Glass and Demonstration of that Method Using SRS Tank 51 Radioactive Sludge and Glass, 10/20/94

13 M:|Waste\Hlcats\WCSystem|WCSTables.xls.SldgInv(new), September 14, 1999.

14 M. E. Jamison, "Characterization of Non-Routine Low-Level Waste from High Level Waste Activities (U)," WSRC-TR-95-0069, March 13, 1995.

15 P. D. Hunt, "Dose-to-Curie Calculations," ESH-HPT-99-0019, Rev. 1, March 2, 1999. 
16 Ross, R. H., Ketusky, E. T., and Petras, R., "HLW Characterization in Support of Low Level Waste Certification: HLW Sludge Beta Screening Tool," WSRC-TR97-0555, Rev. 1, October 8, 1998.

17 SRS-DTC ${ }^{\text {TM }}$ 3.1, WMG, Inc, 16 Bank Street, Peekskill, NY 10566 


\section{Attachment 1}

Development of Scaling Factors for Tanks 40, 42 and 51 
Comparison of Tank 42 PK to Analyzed and WCS-derived Sludge Scaling Factors for Consolidation

\begin{tabular}{|c|c|c|c|c|c|c|c|}
\hline \multirow[b]{2}{*}{ Isotope } & \multicolumn{4}{|c|}{$\begin{array}{c}\text { Concentration of Insoluble Isotope in Sludge } \\
\text { Slurry (uCi/gal)) }\end{array}$} & \multicolumn{3}{|c|}{ Scaling Factors (Ci/Ci Sr-90) } \\
\hline & $\begin{array}{c}\text { Tank } 42 \\
25 \mathrm{~L} \\
\text { Sample } \\
\text { (Ref 1) }\end{array}$ & \begin{tabular}{|c|} 
Tank 42 5L \\
Sample \\
(Ref 2) \\
\end{tabular} & $\begin{array}{l}\text { DWPF } \\
\text { Macro } \\
\text { Batch } 2 \\
\text { Sample } \\
\text { (Ref 3) } \\
\end{array}$ & \begin{tabular}{|c|} 
Average \\
Concentrat \\
ion from \\
Sample \\
Data \\
\end{tabular} & $\begin{array}{c}\text { Average } \\
\text { SFs from } \\
\text { Sample } \\
\text { Data }\end{array}$ & $\begin{array}{c}\text { Tank } 42 \text { WCS } \\
\text { Tables (Ref } \\
4 \text { ) } \\
\end{array}$ & $\begin{array}{l}\text { Tank 42 } \\
\text { Decay- } \\
\text { Corrected } \\
\text { Fill Data } \\
\text { (Ref 5) }\end{array}$ \\
\hline $\mathrm{H}-3$ & & & & & & & \\
\hline C-14 & & & 5.00E-03 & 5.00E-03 & $8.52 E-07$ & 7.55E-08 & $6.70 \mathrm{E}-08$ \\
\hline Ni-59 & & & 7.41E-02 & $7.41 E-02$ & $1.26 \mathrm{E}-05$ & $3.36 \mathrm{E}-05$ & 3.48E-05 \\
\hline Co-60 & $1.96 E+00$ & $9.78 E-01$ & 7.93E-01 & $1.24 \mathrm{E}+00$ & $2.12 E-04$ & 2.10E-03 & 5.60E-04 \\
\hline Se-79 & & & $9.62 \mathrm{E}-02$ & $9.62 \mathrm{E}-02$ & $1.64 \mathrm{E}-05$ & $1.75 \mathrm{E}-05$ & 1.83E-05 \\
\hline Sr-90 & $7.13 E+03$ & $5.61 \mathrm{E}+03$ & $4.88 E+03$ & $5.87 \mathrm{E}+03$ & $1.00 E+00$ & $1.00 \mathrm{E}+00$ & $1.00 E+00$ \\
\hline$Y-90$ & $7.13 E+03$ & $5.61 E+03$ & $4.88 \mathrm{E}+03$ & $5.87 E+03$ & $1.00 \mathrm{E}+00$ & $1.00 \mathrm{E}+00$ & $1.00 E+00$ \\
\hline TC-99 & & & $1.89 \mathrm{E}-01$ & $1.89 E-01$ & $3.22 E-05$ & 2.97E-04 & $3.10 \mathrm{E}-04$ \\
\hline Ru-106 & & $2.95 E+00$ & & $2.95 \mathrm{E}+00$ & $5.02 E-04$ & 1.41E-07 & 4.60E-08 \\
\hline Rh-106 & & & & & & $1.41 \mathrm{E}-07$ & 4.60E-08 \\
\hline Sb-125 & & $1.36 \mathrm{E}+00$ & $3.02 \mathrm{E}-01$ & 8.32E-01 & $1.42 E-04$ & $1.54 \mathrm{E}-04$ & $7.45 E-05$ \\
\hline Sn-126 & & & $3.70 E-02$ & $3.70 \mathrm{E}-02$ & $6.29 E-06$ & 1.63E-05 & 1.69E-05 \\
\hline $1-129$ & & & $1.23 \mathrm{E}-03$ & 1.23E-03 & $2.10 \mathrm{E}-07$ & $1.03 E-09$ & $1.08 \mathrm{E}-09$ \\
\hline Cs-134 & & & & & & $1.08 \mathrm{E}-05$ & $4.26 \mathrm{E}-06$ \\
\hline Cs-135 & & & 7.76E-04 & $7.76 \mathrm{E}-04$ & $1.32 \mathrm{E}-07$ & $1.98 \mathrm{E}-07$ & \\
\hline Cs-137 & $1.70 E+02$ & $2.07 E+02$ & $1.67 E+02$ & $1.81 E+02$ & $3.09 E-02$ & $5.52 E-02$ & $5.54 \mathrm{E}-02$ \\
\hline $\mathrm{Ba}-137 \mathrm{~m}$ & $1.61 \mathrm{E}+02$ & $1.96 \mathrm{E}+02$ & $1.58 \mathrm{E}+02$ & $1.71 E+02$ & $2.92 \mathrm{E}-02$ & $5.22 \mathrm{E}-02$ & 5.24E-02 \\
\hline $\mathrm{Ce}-144$ & & $2.61 E+00$ & & $2.61 E+00$ & $4.44 E-04$ & 4.09E-08 & 9.33E-09 \\
\hline Pm-147 & & & & & & 4.03E-03 & 2.01E-03 \\
\hline Eu-154 & $2.05 E+01$ & $1.74 \mathrm{E}+01$ & $1.16 \mathrm{E}+01$ & $1.65 E+01$ & 2.81E-03 & $1.01 \mathrm{E}-02$ & $3.02 E-02$ \\
\hline U-233. & 3.39E-02 & $4.36 \mathrm{E}-02$ & 4.94E-02 & $4.23 E-02$ & 7.20E-06 & $1.80 \mathrm{E}-06$ & $9.80 E=06$ \\
\hline U-234 & 2.36E-02 & $3.09 \mathrm{E}-02$ & $3.27 E-02$ & $2.91 E-02$ & $4.95 \mathrm{E}-06$ & $6.62 \mathrm{E}-07$ & $6.84 \mathrm{E}-06$ \\
\hline U-235 & $3.94 E-04$ & $3.90 E-04$ & $3.18 E-04$ & 3.67E-04 & $6.26 \mathrm{E}-08$ & $1.56 E-08$ & 1.14E-07 \\
\hline Np-237 & & $1.55 \mathrm{E}-02$ & $1.46 \mathrm{E}-02$ & 1.51E-02 & 2.57E-06 & 5.45E-07 & $1.29 \mathrm{E}-06$ \\
\hline Pu-238 & $1.11 E+02$ & $1.04 E+02$ & $1.13 E+02$ & $1.09 E+02$ & $1.86 \mathrm{E}-02$ & $7.69 \mathrm{E}-03$ & $3.12 E-02$ \\
\hline Pu-239 & $5.50 E+00$ & $5.02 E+00$ & $5.53 E+00$ & $5.35 E+00$ & $9.11 \mathrm{E}-04$ & $3.07 E-04$ & $1.55 E-03$ \\
\hline Pu-240 & $1.66 \mathrm{E}+00$ & $1.80 \mathrm{E}+00$ & $2.01 E+00$ & $1.82 E+00$ & 3.11E-04 & $1.10 \mathrm{E}-04$ & $4.68 \mathrm{E}-04$ \\
\hline Pu-241 & $5.96 \mathrm{E}+01$ & $3.39 E+01$ & $3.21 E+01$ & $4.19 E+01$ & 7.13E-03 & $6.54 \mathrm{E}-04$ & 1.67E-02 \\
\hline Pu-242 & $3.85 \mathrm{E}-03$ & $3.31 \mathrm{E}-03$ & $4.19 \mathrm{E}-03$ & $3.78 \mathrm{E}-03$ & $6.44 \mathrm{E}-07$ & $1.01 \mathrm{E}-07$ & $2.94 E-05$ \\
\hline Am-241 & $7.42 E+00$ & $8.39 E+00$ & $7.54 \mathrm{E}+00$ & $7.78 E+00$ & 1.33E-03 & $1.33 E-03$ & $2.08 \mathrm{E}-03$ \\
\hline $\mathrm{Cm}-244$. & $7.64 \mathrm{E}+00$ & $5.91 \mathrm{E}+00$ & $5.00 \mathrm{E}+00$ & $6.19 E+00$ & $1.05 E-03$ & 8.68E-06 & 8.24E-06 \\
\hline Total & $1.48 E+04$ & $1.18 E+04$ & $1.03 E+04$ & $1.23 E+04$ & $2.09 E+00$ & $2.13 E+00$ & $2.19 E+00$ \\
\hline
\end{tabular}

Bold isotopes=PA Rads for EAV

1. WSRC-RP-94-730, M. S. Hay and N. E. Bibler, Characterization and Sludge Washing Studies of Tank 42H Sludge (U), 7/27/94

2. WSRC-RP-98-00406, M. S. Hay and N. E. Bibler, Characterization and Decant of Tank 42H Sludge Sample ESP-200, 6/12/98

3. WSRC-RP-0436, T. L Fellinger and N. E. Bibler, Characterization of and Waste Acceptance Radionuclides to be Reported for DWPF Macro Batch 2 (ESP 215-ESP-221) (U), June 21, 1999

4. M:IWastelHicatsiWCSystemiWCSTables.xls.Sidglnv(new), 9/14/99

5. WSRC-TR-94-0562, G. K. Georgeton and J. R. Hester, "Characterization of Radionuclides in HLW Sludge Based on Isotopic Distribution in Irradiated Assemblies (U)," WSRC-TR-94-0562, Rev. 1, January 27, 1995 
Comparison of Tank 42 PK to Analyzed and WCS-derived Sludge Scaling Factors for Consolidation

\begin{tabular}{|c|c|c|c|c|c|c|c|}
\hline \multirow[b]{3}{*}{ Isotope } & \multicolumn{7}{|c|}{ Calculation of Scaling Factors from 25L Sample (Ref 1) } \\
\hline & \multicolumn{3}{|c|}{ Sludge Slurry } & \multicolumn{2}{|c|}{ Interstitial Supernate } & \multirow[b]{2}{*}{$\begin{array}{c}\text { Adjusted } \\
\text { uCi/g } \\
\text { Sludge } \\
\text { Solids }\end{array}$} & \multirow[b]{2}{*}{ SF } \\
\hline & $\begin{array}{c}\mathrm{wt} \%(\mathrm{~g} / \mathrm{g} \\
\text { total } \\
\text { solids) }\end{array}$ & $\begin{array}{c}\text { Specific } \\
\text { activity, } \\
\text { Ci/g }\end{array}$ & $\begin{array}{l}\text { uCi/g total } \\
\text { solids }\end{array}$ & $\begin{array}{c}w t \%(g / g \\
\text { supernate) }\end{array}$ & $\begin{array}{c}\text { uCi/ml } \\
\text { Supernate }\end{array}$ & & \\
\hline $\mathrm{H}-3$ & & $9.71 \mathrm{E}+03$ & & & & & \\
\hline C-14 & & $4.46 \mathrm{E}+00$ & 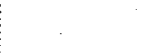 & & & & \\
\hline $\mathrm{Ni}-59$ & & 8.08E-02 & & & & & \\
\hline Co-60 & & $1.13 E+03$ & $1.55 E+00$ & & & $1.96 \mathrm{E}+00$ & 2.75E-04 \\
\hline Se-79 & & $6.96 \mathrm{E}-02$ & & & & & \\
\hline Sr-90 & & $1.39 E+02$ & $5.63 E+03$ & & & $7.13 E+03$ & $1.00 \mathrm{E}+00$ \\
\hline$Y-90$ & & $5.43 E+05$ & & & & $7.13 E+03$ & $1.00 E+00$ \\
\hline Tc-99 & & $1.70 E-02$ & & & & & \\
\hline Ru-106 & & $1.47 E+09$ & & & & & \\
\hline Rh-106 & & $2.71 \mathrm{E}+09$ & & & & & \\
\hline Sb-125 & & $1.03 E+03$ & & & $:$ & & \\
\hline Sn-126 & & $2.84 \mathrm{E}-02$ & & & & & \\
\hline $1-129$ & & 1.77E-04 & & & & & \\
\hline Cs-134 & & $1.29 E+03$ & & & & & \\
\hline Cs-135 & & $1.15 E-03$ & & & & & \\
\hline Cs-137 & & $8.65 \mathrm{E}+01$ & $1.56 E+02$ & & $8.25 E+00$ & $1.70 \mathrm{E}+02$ & 2.39E-02 \\
\hline $\begin{array}{c}\mathrm{Ba}-137 \mathrm{~m} \\
\mathrm{Ce}-144\end{array}$ & & $3.19 \mathrm{E}+03$ & & & & $1.61 \mathrm{E}+02$ & $2.26 \mathrm{E}-02$ \\
\hline Pm-147. & & $9.27 \mathrm{E}+02$ & & & & & \\
\hline Eu-154 & & $2.64 \mathrm{E}+02$ & $1.62 E+01$ & & & $2.05 \mathrm{E}+01$ & $2.88 E-03$ \\
\hline U-233 & $2.86 \mathrm{E}-04$ & $9.65 \mathrm{E}-03$ & $2.76 \mathrm{E}-02$ & 2.99E-08 & $3.06 \mathrm{E}-04$ & $3.39 \mathrm{E}-02$ & 4.76E-06 \\
\hline U-234 & 3.09E-04 & $6.22 E-03$ & $1.92 E-02$ & $3.23 E-08$ & 2.13E-04 & 2.36E-02 & 3.31E-06 \\
\hline U-235 & $1.48 \mathrm{E}-02$ & 2.16E-06 & $3.20 \mathrm{E}-04$ & $1.55 \mathrm{E}-06$ & $3.55 \mathrm{E}-06$ & $3.94 E-04$ & $5.52 E-08$ \\
\hline Np-237 & & $7.05 \mathrm{E}-04$ & & & & & \\
\hline Pu-238 & $5.14 E-04$ & $1.71 E+01$ & $8.79 E+01$ & $2.88 E-10$ & $5.22 E-03$ & $1.11 E+02$ & $1.56 \mathrm{E}-02$ \\
\hline Pu-239 & $7.00 \mathrm{E}-03$ & $6.20 \mathrm{E}-02$ & $4.34 \mathrm{E}+00$ & $3.92 \mathrm{E}-09$ & $2.58 \mathrm{E}-04$ & $5.50 \mathrm{E}+00$ & $7.71 E-04$ \\
\hline Pu-240 & $5.79 E-04$ & $2.27 \mathrm{E}-01$ & $1.31 E+\infty 0$ & $3.24 \mathrm{E}-10$ & $7.80 \mathrm{E}-05$ & $1.66 \mathrm{E}+00$ & 2.33E-04 \\
\hline Pu-241 & 4.57E-05 & $1.03 E+02$ & $4.71 \mathrm{E}+01$ & $2.56 \mathrm{E}-11$ & 2.79E-03 & $5.96 \mathrm{E}+01$ & 8.36E-03 \\
\hline Pu-242 & $7.73 E-05$ & $3.93 \mathrm{E}-03$ & $3.04 \mathrm{E}-03$ & $4.33 E-11$ & $1.80 \mathrm{E}-07$ & $3.85 E-03$ & $5.40 \mathrm{E}-07$ \\
\hline$A m-241$ & & $3.43 E+00$ & $5.86 \mathrm{E}+00$ & & & $7.42 \mathrm{E}+00$ & $1.04 \mathrm{E}-03$ \\
\hline $\mathrm{Cm}-244$ & & $8.09 E+01$ & $6.03 E+00$ & & & $7.64 \mathrm{E}+00$ & $1.07 \mathrm{E}-03$ \\
\hline Total & & & & & & $1.48 E+04$ & \\
\hline & given: & & & & calculated: & & \\
\hline & $\mathrm{g}$ diss sids & g slurry & $7.6 \%$ & & g slurry/L sl & urry & 1170 \\
\hline & $\mathrm{g}$ tot sids/g & slurry & $28.0 \%$ & & $\mathrm{~g}$ diss solids & / L slurry & 69.03 \\
\hline & $\mathrm{g}$ insol slds & g slurry & $22.1 \%$ & & L supernate & L slurry & 0.86 \\
\hline & g sol sids $/ 9$ & slurry & $5.9 \%$ & 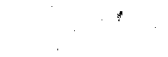 & $g$ insol sids & L slurry & 258.57 \\
\hline & spg supern & & 1.06 & & $\mathrm{~g}$ total solid & s/L slurry & 327.6 \\
\hline & spg slurry & & 1.17 & & $\mathrm{~g}$ insol slds/ & tot sids & $78.9 \%$ \\
\hline & $\mathrm{g} U / \mathrm{g}$ supe & nate & $2.78 \mathrm{E}-04$ & & & & \\
\hline & $\mathrm{g} \mathrm{U} / \mathrm{g}$ slurn & & $2.66 \mathrm{E}+00$ & & & & \\
\hline & g Pu/g sup & inate & 4.60E-09 & & & & \\
\hline & g Pu/g slur & & $8.22 E-03$ & & & & \\
\hline
\end{tabular}


Comparison of Tank 42 PK to Analyzed and WCS-derived Sludge Scaling Factors for Consolidation

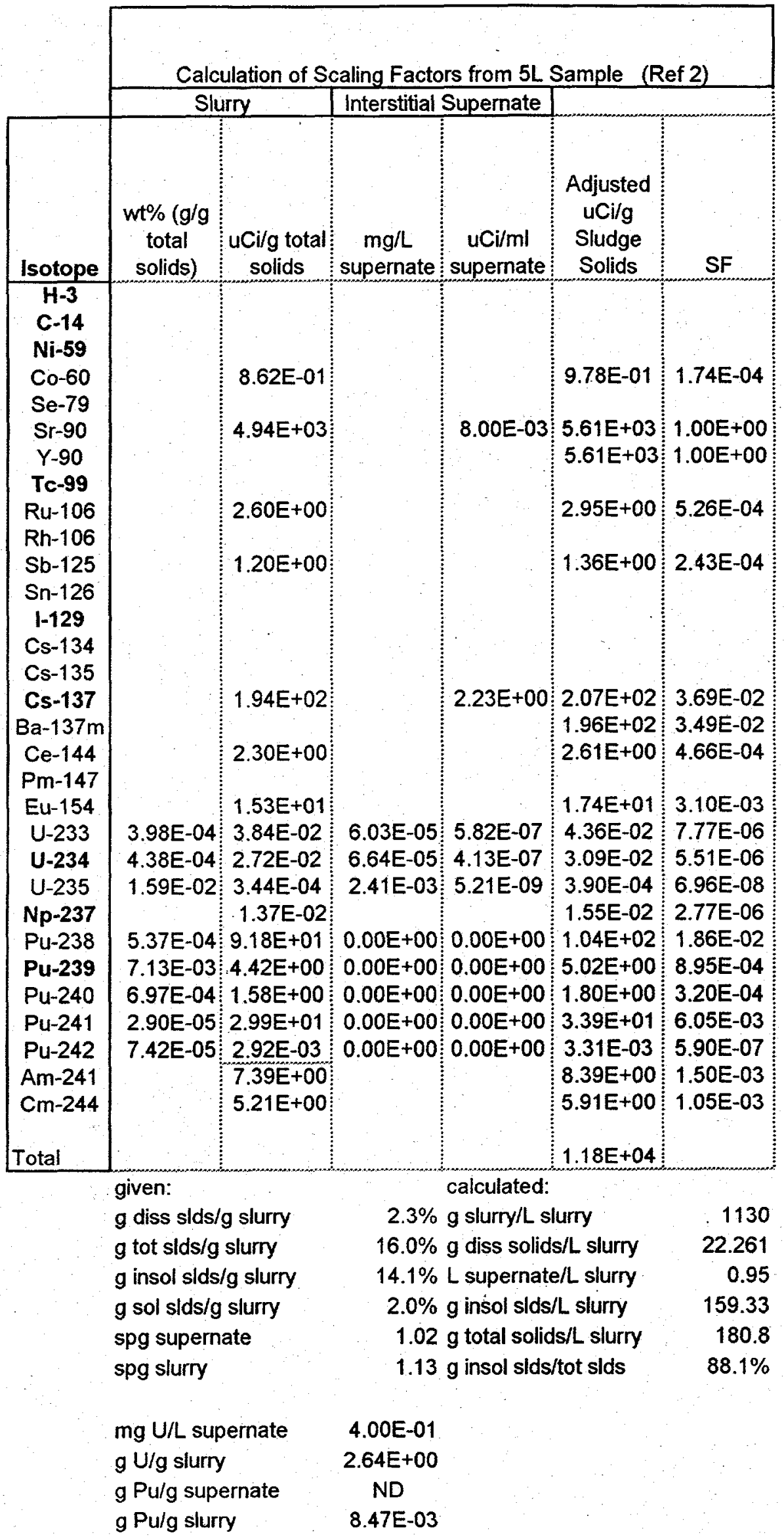


Comparison of Tank 42 PK to Analyzed and WCS-derived Sludge Scaling Factors for Consolidation

\begin{tabular}{|c|c|c|c|c|c|c|}
\hline \multirow[b]{3}{*}{ Isotope } & \multicolumn{6}{|c|}{$\begin{array}{l}\text { Calculation of Scaling Factors from Tank } 42 / 51 \text { Sample (DWPF } \\
\text { Macro Batch 2) (Ref 3) }\end{array}$} \\
\hline & \multicolumn{2}{|c|}{ Slurry } & \multicolumn{2}{|c|}{ Interstitial Supernate } & \multirow{2}{*}{\multicolumn{2}{|c|}{$\begin{array}{l}\text { Adjusted } \\
\text { uCi/g } \\
\text { Sludge } \\
\text { Solids }\end{array}$}} \\
\hline & $\begin{array}{c}\text { wt\% (g/g } \\
\text { total } \\
\text { solids) }\end{array}$ & $\begin{array}{l}\text { uCi/g total } \\
\text { solids }\end{array}$ & $\begin{array}{c}\mathrm{mg} / \mathrm{L} \\
\text { supernate }\end{array}$ & $\begin{array}{c}\text { uCi/ml } \\
\text { supernate }\end{array}$ & & \\
\hline $\mathrm{H}-3$ & & & & & & \\
\hline $\begin{array}{r}\mathrm{C}-14 \\
\mathrm{Ni}-59\end{array}$ & $\begin{array}{l}9.91 \mathrm{E}-08 \\
8.10 \mathrm{E}-05\end{array}$ & $\begin{array}{l}4.42 E-03 \\
6.54 E-02\end{array}$ & & & $\begin{array}{l}5.00 \mathrm{E}-03 \\
741 \mathrm{E}-02\end{array}$ & 1.03E-06 \\
\hline Co-60 & 6.19E-08 & 7.00E-01 & & & $7.93 E-01$ & 1.63E-04 \\
\hline Se-79 & $1.22 \mathrm{E}-04$ & $8.49 \mathrm{E}-02$ & & & $9.62 \mathrm{E}-02$ & $1.97 \mathrm{E}-05$ \\
\hline Sr-90 & 3.10E-03 & $4.31 E+03$ & & 7.83E-03 & $4.88 E+03$ & $1.00 E+00$ \\
\hline$Y-90$ & $3.10 E-03$ & $1.68 E+07$ & & & $4.88 E+03$ & $1.00 E+00$ \\
\hline Tc-99 & 1.10E-03 & 1.87E-01 & 2.68E-01 & & 1.89E-01 & $3.88 \mathrm{E}-05$ \\
\hline Ru-106 & & & & & & \\
\hline Rh-106 & & & & & & \\
\hline $\mathrm{Sb}-125$ & $2.58 \mathrm{E}-08$ & 2.67E-01 & & & $3.02 \mathrm{E}-01$ & 6.19E-05 \\
\hline Sn-126 & $1.15 \mathrm{E}-04$ & $3.26 \mathrm{E}-02$ & & & 3.70E-02 & 7.58E-06 \\
\hline |-129 & $6.16 \mathrm{E}-04$ & $1.09 \mathrm{E}-03$ & & & 1.23E-03 & $2.53 E-07$ \\
\hline Cs-134 & & & & & & \\
\hline Cs-135 & $6.45 E-05$ & $7.42 \mathrm{E}-04$ & $1.14 \mathrm{E}-02$ & & $7.76 \mathrm{E}-04$ & $1.59 \mathrm{E}-07$ \\
\hline Cs-137 & $1.84 E-04$ & $1.59 E+02$ & $3.21 E-02$ & $2.44 E+00$ & $1.67 E+02$ & $3.42 E-02$ \\
\hline $\mathrm{Ba}-137 \mathrm{~m}$ & & & & & $1.58 E+02$ & $3.23 \mathrm{E}-02$ \\
\hline $\mathrm{Ce}-144$ & & & & & & \\
\hline$P m-147$ & & & & & & \\
\hline Eu-154 & $3.89 \mathrm{E}-06$ & $1.03 E+01$ & & & $1.16 \mathrm{E}+01$ & $2.38 E-03$ \\
\hline U-233 & $4.52 E-04$ & $4.36 E-02$ & $9.91 \mathrm{E}-05$ & & $4.94 \mathrm{E}-02$ & 1.01E-05 \\
\hline$U-234$ & $4.65 E-04$ & $2.89 \mathrm{E}-02$ & $1.02 E-04$ & & $3.27 \mathrm{E}-02$ & 6.71E-06 \\
\hline U-235 & $1.30 \mathrm{E}-02$ & $2.81 E-04$ & $3.14 \mathrm{E}-03$ & & $3.18 E-04$ & 6.53E-08 \\
\hline Np-237 & $1.83 E-03$ & $1.29 E-02$ & & & $1.46 \mathrm{E}-02$ & 3.00E-06 \\
\hline Pu-238 & $5.81 E-04$ & $9.94 E+01$ & & & $1.13 E+02$ & 2.31E-02 \\
\hline Pu-239 & $7.87 \mathrm{E}-03$ & $4.88 E+00$ & & & $5.53 E+00$ & 1.13E-03 \\
\hline Pu-240 & $7.82 \mathrm{E}-04$ & $1.78 E+00$ & & & $2.01 E+00$ & 4.12E-04 \\
\hline Pu-241 & $2.75 \mathrm{E}-05$ & $2.83 E+01$ & & & $3.21 \mathrm{E}+01$ & $6.58 \mathrm{E}-03$ \\
\hline Pu-242 & $9.41 E-05$ & $3.70 E-03$ & & & 4.19E-03 & 8.59E-07 \\
\hline$A m-241$ & $1.94 E-04$ & $6.66 E+00$ & & & $7.54 E+00$ & $1.55 E-03$ \\
\hline $\mathrm{Cm}-244$ & $5.46 \mathrm{E}-06$ & $4.42 E+00$ & & & $5.00 E+00$ & $1.03 E-03$ \\
\hline Total & & & & & $1.03 E+04$ & \\
\hline & given: & $\therefore$ & & calculated: & & \\
\hline & g diss slds/ & $g$ slürry & $2.6 \%$ & g slurry/L s & lurry & 1100 \\
\hline & $g$ tot slds $/ g$ & slurry & $18.8 \%$ & g diss solid & s/L slurry & 24.2 \\
\hline & $g$ insol slds & Ig slurry & $16.6 \%$ & L supernat & /L slurry & 0.89 \\
\hline & g sol sids $/ g$ & slurry & $2.2 \%$ & $g$ insol sids & L slurry & 182.6 \\
\hline & spg supern & & 1.03 & $\mathrm{~g}$ total solic & s/L slurry & 206.8 \\
\hline & spg slurry & & 1.1 & $\mathrm{~g}$ insol slds & tot slds & $88.3 \%$ \\
\hline
\end{tabular}

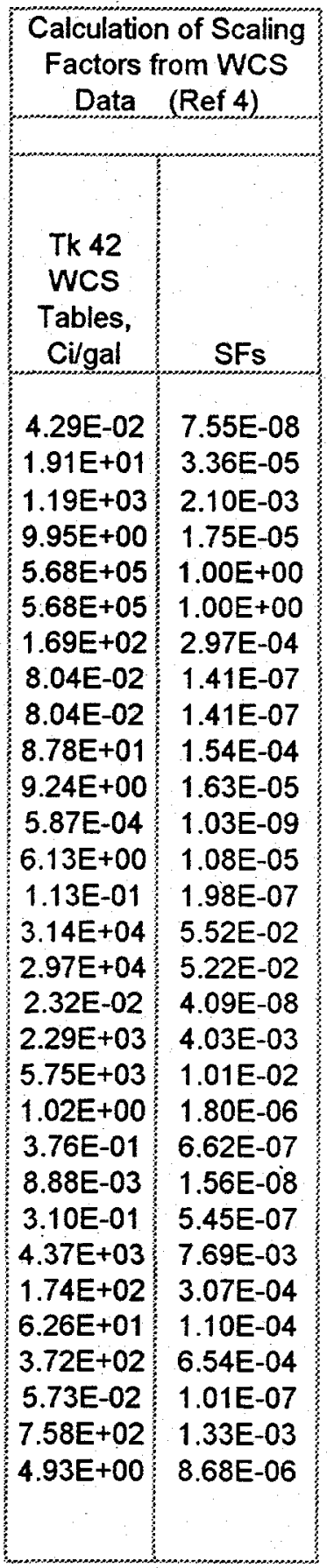

Calculation of Scaling Factors from Fill Data (Ref 5)

\begin{tabular}{|c|c|}
\hline $\begin{array}{l}\text { Tk } 42 \text { Fill } \\
\text { Data, SFs }\end{array}$ & $\begin{array}{c}\text { Decay } \\
\text { Corrected } \\
\text { to Year } \\
2000\end{array}$ \\
\hline $\begin{array}{l}2.97 \mathrm{E}-08 \\
1.54 \mathrm{E}-05\end{array}$ & $\begin{array}{l}3.35 E-08 \\
1.74 E-05\end{array}$ \\
\hline $2.80 E-04$ & $2.80 E-04$ \\
\hline 8.10E-06 & $9.16 E-06$ \\
\hline $5.00 \mathrm{E}-01$ & $5.00 E-01$ \\
\hline $5.00 \mathrm{E}-01$ & $5.00 E-01$ \\
\hline 1.37E-04 & $1.55 E-04$ \\
\hline $6.40 \mathrm{E}-07$ & 2.30E-08 \\
\hline $6.40 \mathrm{E}-07$ & $2.30 \mathrm{E}-08$ \\
\hline 1.19E-04 & $3.73 E-05$ \\
\hline 7.48E-06 & 8.47E-06 \\
\hline 4.76E-10 & 5.39E-10 \\
\hline $1.02 E-05$ & $2.13 \mathrm{E}-06$ \\
\hline $2.77 \mathrm{E}-02$ & 2.77E-02 \\
\hline $2.62 \mathrm{E}-02$ & $2.62 E-02$ \\
\hline 3.55E-07 & 4.67E-09 \\
\hline $3.33 E-03$ & $1.00 \mathrm{E}-03$ \\
\hline $1.66 \mathrm{E}-02$ & $1.51 \mathrm{E}-02$ \\
\hline 4.90E-06 & $4.90 \mathrm{E}-06$ \\
\hline 3.42E-06 & $3.42 \mathrm{E}-06$ \\
\hline $5.68 \mathrm{E}-08$ & $5.68 \mathrm{E}-08$ \\
\hline 5.70E-07 & $6.44 \mathrm{E}-07$ \\
\hline $1.56 \mathrm{E}-02$ & $1.56 \mathrm{E}-02$ \\
\hline 7.73E-04 & 7.73E-04 \\
\hline 2.34E-04 & $2.34 E-04$ \\
\hline 8.36E-03 & $8.36 \mathrm{E}-03$ \\
\hline $1.47 \mathrm{E}-05$ & $1.47 E-05$ \\
\hline $1.04 \mathrm{E}-03$ & $1.04 E-03$ \\
\hline \multirow[t]{2}{*}{ 4.44E-06 } & $4.12 E-06$ \\
\hline & $1.10 E+00$ \\
\hline
\end{tabular}

$\mathrm{mg}$ U/L supernate g U/g slurry $1.94 E+00$

g Pu/g supernate g Pu/g slurry 


\begin{tabular}{|c|c|c|c|c|c|c|c|c|}
\hline \multirow[b]{2}{*}{ Isotope } & \multicolumn{5}{|c|}{ Concentration of Isotope in Insoluble Sludge Solids (uCi/g) } & \multicolumn{3}{|c|}{ Scaling Factors ( $\mathrm{Ci} / \mathrm{Ci} \mathrm{Sr}-90)$} \\
\hline & 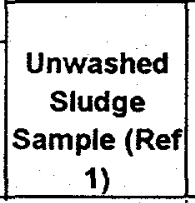 & $\begin{array}{l}\text { Washed } \\
\text { Sludge } \\
\text { Sample } \\
\text { (Ref 1) } \\
\end{array}$ & $\begin{array}{l}\text { Sludge } \\
\text { Sample } \\
\text { (Ref 2) }\end{array}$ & \begin{tabular}{|c|} 
Sludge \\
Sample (Ref \\
3 )
\end{tabular} & $\begin{array}{c}\text { Average } \\
\text { concentration } \\
\text { from Sample } \\
\text { Data }\end{array}$ & $\begin{array}{l}\text { Scaling } \\
\text { Factors } \\
\text { from } \\
\text { Analytical } \\
\text { Data } \\
\end{array}$ & $\begin{array}{c}\text { Tank } 51 \\
\text { WCS } \\
\text { (Ref 4) }\end{array}$ & $\begin{array}{l}\text { Tank } 51 \\
\text { Decay- } \\
\text { Corrected } \\
\text { Fill Data } \\
\text { (Ref 5) } \\
\end{array}$ \\
\hline $\mathrm{H}-3$ & & & & & & & & \\
\hline C-14 & & & & & & & $1.59 E-06$ & $1.86 \mathrm{E}-06$ \\
\hline $\mathrm{Ni}-59$ & & & $2.54 \mathrm{E}-02$ & & $2.54 \mathrm{E}-02$ & $2.84 E-05$ & $1.05 E-04$ & $1.20 E-04$ \\
\hline $\mathrm{Co}-60$ & $1.36 E+\infty$ & $1.19 \mathrm{E}+00$ & & & $1.28 \mathrm{E}+\infty 0$ & 1.43E-03 & 3.64E-03 & 3.16E-03 \\
\hline Se-79 & & & $1.46 E-02$ & & $1.46 \mathrm{E}-02$ & $1.63 \mathrm{E}-05$ & $1.62 \mathrm{E}-05$ & $1.66 \mathrm{E}-05$ \\
\hline Sr-90 & $9.26 \mathrm{E}+02$ & $8.21 E+02$ & $8.18 \mathrm{E}+02$ & $1.01 E+03$ & $8.95 E+02$ & $1.00 E+\infty 0$ & $1.00 E+00$ & $1.00 E+00$ \\
\hline$Y-90$ & $9.26 E+02$ & $8.21 E+02$ & $8.18 \mathrm{E}+02$ & $1.01 E+03$ & $8.95 E+02$ & $1.00 E+\infty 0$ & $1.00 E+00$ & $1.00 E+00$ \\
\hline Tc-99 & & & 2.89E-01 & $2.88 \mathrm{E}-01$ & $2.88 E-01$ & $3.22 \mathrm{E}-04$ & $2.77 \mathrm{E}-04$ & $2.86 \mathrm{E}-04$ \\
\hline Ru-106 & & & & & & & $9.96 \mathrm{E}-07$ & $4.72 \mathrm{E}-07$ \\
\hline Rh-106 & & & & & & & $9.96 \mathrm{E}-07$ & $4.72 \mathrm{E}-07$ \\
\hline Sb-125 & & & & & & & $8.36 \mathrm{E}-04$ & $6.28 \mathrm{E}-04$ \\
\hline$S n-126$ & . & & $8.54 \mathrm{E}-03$ & $-=$ & $8.54 E-03$ & $9.55 \mathrm{E}-06$ & $2.21 \mathrm{E}-05$ & $2.38 \mathrm{E}-05$ \\
\hline $\mathrm{I}-129$ & & & & & & & 1.13E-09 & $1.19 \mathrm{E}-09$ \\
\hline Cs-134 & & & & & & & $5.40 E-05$ & 3.16E-05 \\
\hline Cs-135 & & & & & & & $1.85 E-07$ & \\
\hline Cs-137 & 7.41E+01 & $6.46 E+01$ & $6.49 \mathrm{E}+01$ & $5.80 E+01$ & $6.54 E+01$ & 7.31E-02 & 5.99E-02 & $1.20 \mathrm{E}-01$ \\
\hline $\mathrm{Ba}-137 \mathrm{~m}$ & $7.01 E+01$ & $6.11 \mathrm{E}+01$ & $6.14 E+01$ & $5.48 E+01$ & $6.18 E+01$ & $6.91 E-02$ & $5.67 \mathrm{E}-02$ & $1.13 E-01$ \\
\hline Ce-144 & & & & & & & $2.56 \mathrm{E}-07$ & 8.98E-08 \\
\hline Pm-147 & & & & & & & 1.99E-02 & $1.48 \mathrm{E}-02$ \\
\hline Eu-154 & $1.92 \mathrm{E}+00$ & $1.81 E+\infty 0$ & & & $1.86 E+\infty 0$ & $2.08 \mathrm{E}-03$ & $1.22 \mathrm{E}-02$ & 2.50E-02 \\
\hline$U-233$ & 3.76E-02 & $3.40 \mathrm{E}-02$ & $3.41 \mathrm{E}-02$ & $2.41 \mathrm{E}-02$ & 3.24E-02 & 3.62E-05 & 2.96E-06 & 3. $22 \mathrm{E}-07$. \\
\hline U-234 & $3.73 \mathrm{E}-02$ & 3.36E-02 & 3.33E-02 & 2.11E-02 & $3.14 \mathrm{E}-02$ & $3.50 \mathrm{E}-05$ & $1.88 \mathrm{E}-06$ & $1.03 E-21$ \\
\hline U-235 & $4.90 \mathrm{E}-04$ & 4.39E-04 & 4.53E-04 & $3.46 E-04$ & 4.32E-04 & 4.83E-07 & 2.05E-07 & $2.96 E-09$ \\
\hline $\mathrm{Np}-237$ & & & 1.85E-02 & 1.06E-02 & 1.45E-02 & 1.62E-05 & 1.15E-06 & 4.42E-05 \\
\hline Pu-238 & $1.43 E+02$ & $1.78 E+02$ & 1.79E+02 & $8.55 E+01$ & $1.47 \mathrm{E}+02$ & $1.64 \mathrm{E}-01$ & 4.69E-02 & $7.26 \mathrm{E}-03$ \\
\hline Pu-239 & $1.06 \mathrm{E}+01$ & $8.68 \mathrm{E}+00$ & $8.93 E+00$ & $4.84 E+00$ & $8.26 E+\infty 0$ & $9.23 E-03$ & $5.47 \mathrm{E}-03$ & $7.72 \mathrm{E}-05$ \\
\hline Pu-240 & $3.60 E+00$ & & $2.35 E+00$ & $1.59 E+00$ & $2.51 E+\infty 0$ & 2.81E-03 & 1.39E-03 & $5.38 \mathrm{E}-05$ \\
\hline Pu-241 & & & 4.18E+01 & $1.96 \mathrm{E}+01$ & 3.07E+01 & $3.43 E-02$ & 7.06E-03 & $1.88 \mathrm{E}-03$ \\
\hline Pu-242 & & & $2.11 \mathrm{E}-03$ & $3.26 \mathrm{E}-03$ & 2.69E-03 & 3.00E-06 & $1.63 \mathrm{E}-06$ & 7.84E-08 \\
\hline$A m-241$ & $9.69 \mathrm{E}+00$ & $7.92 E+00$ & $8.09 E+\infty 0$ & $8.24 E+\infty$ & $8.48 E+00$ & $9.48 \mathrm{E}-03$ & $6.39 \mathrm{E}-04$ & 4.60E-04 \\
\hline $\mathrm{Cm}-244$ & $1.02 E+02$ & $1.57 E+01$ & $1.59 E+01$ & $1.54 E+01$ & $3.74 E+01$ & 4.18E-02 & 6.59E-06 & $4.56 \mathrm{E}-10$ \\
\hline Total & $2.27 E+03$ & $1.98 E+03$ & $1.20 \mathrm{E}+03$ & $1.26 E+03$ & & $2.41 E+\infty$ & $2.22 E+\infty 0$ & \\
\hline
\end{tabular}

1. WSRC-RP-95-1003, M. S. Hay and N.E. Bibler, The Characterization and Centrifuge-Settled Washing of a Tank 51H Sluge Sample Obtained in October 1995(U), 11/25/95

2. WSRC-TR-95-0487, N. E. Bibler and O. B. Hodoh, Calculating Waste Acceptance Radionuclides in DWPF Tank 51 Sludge Only Glass, Rev. 1, 10/15/96

3. WSRC-TR-94-0505, N. E. Bibler,W. F. Kinard, R. A. Dewberry and C. J. Coleman, A Method for the Determination of Waste Acceptance Radionuclides in DWPF Glass and Demonstration of that Method Using SRS Tank 51 Radioactive Sludge and Glass. 10/20/94

4. M:WasteHHicatsiWCSystemiWCSTables.xls.SIdgInv(new), 9/14/99

5. WSRC-TR-94-0562, G. K. Georgeton and J. R. Hester, "Characterization of Radionuclides in HLW Sludge Based on Isotopic Distribution in Irradiated Assemblies (U)," WSRC-TR-94-0562, Rev. 1, January 27, 1995 


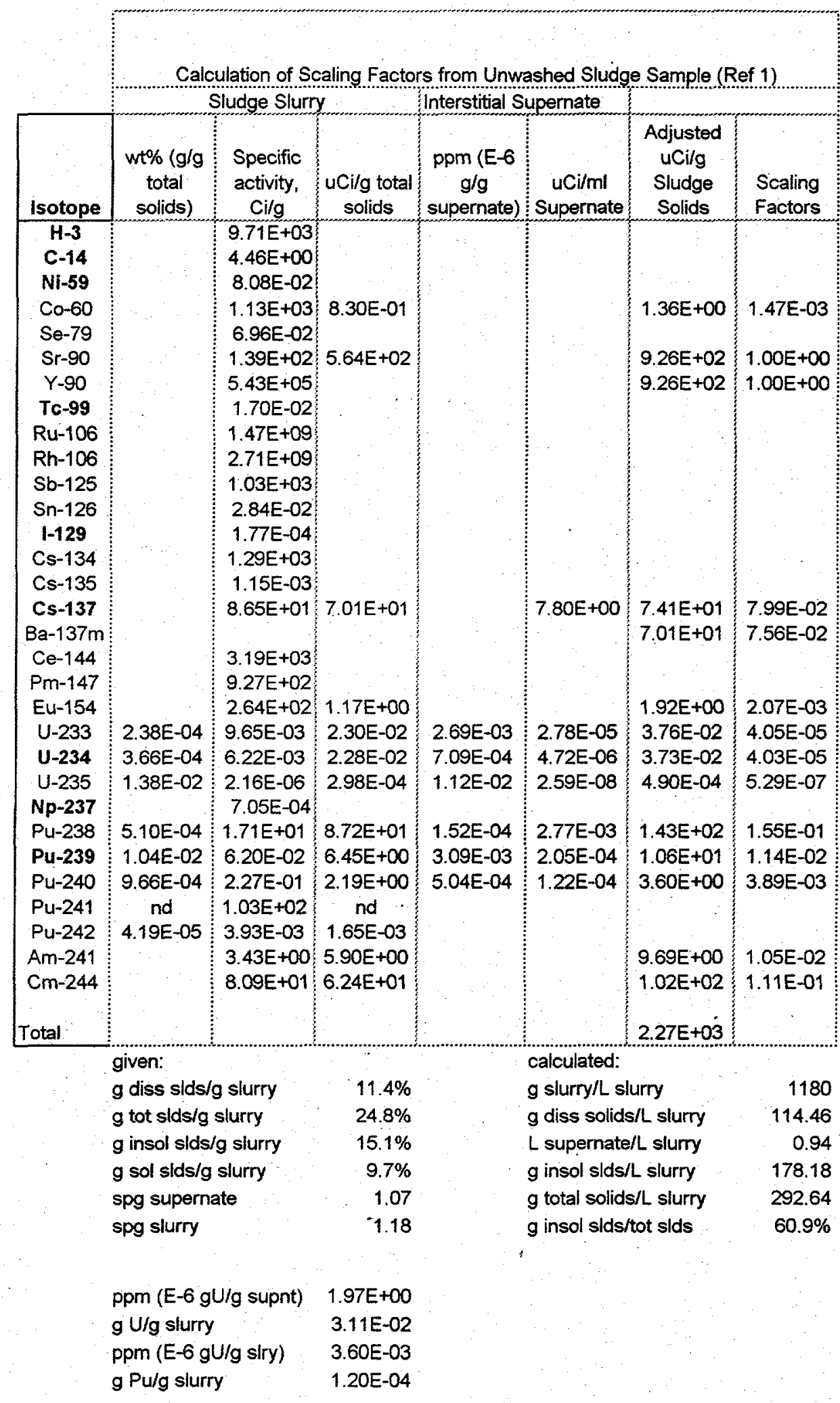




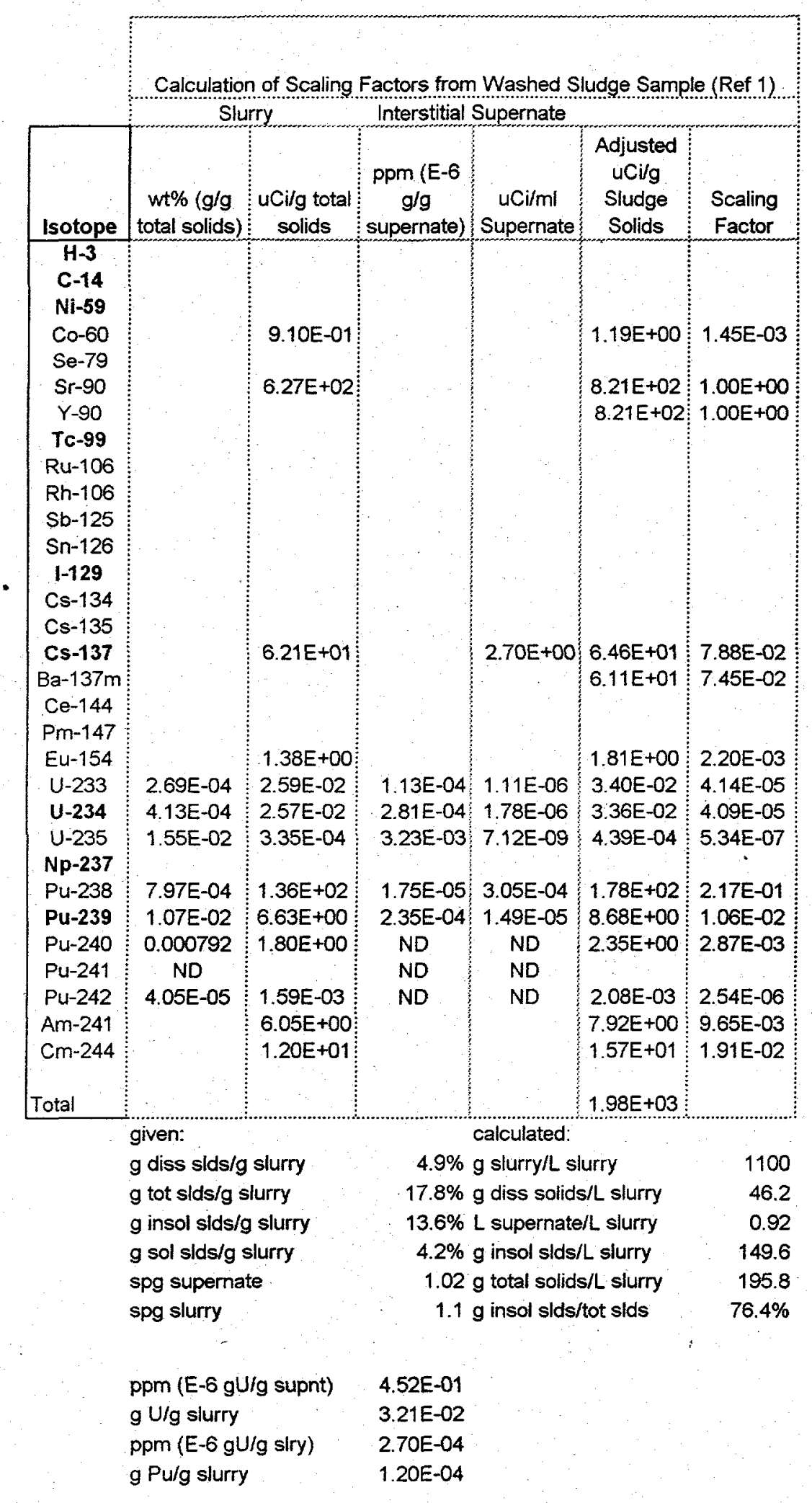

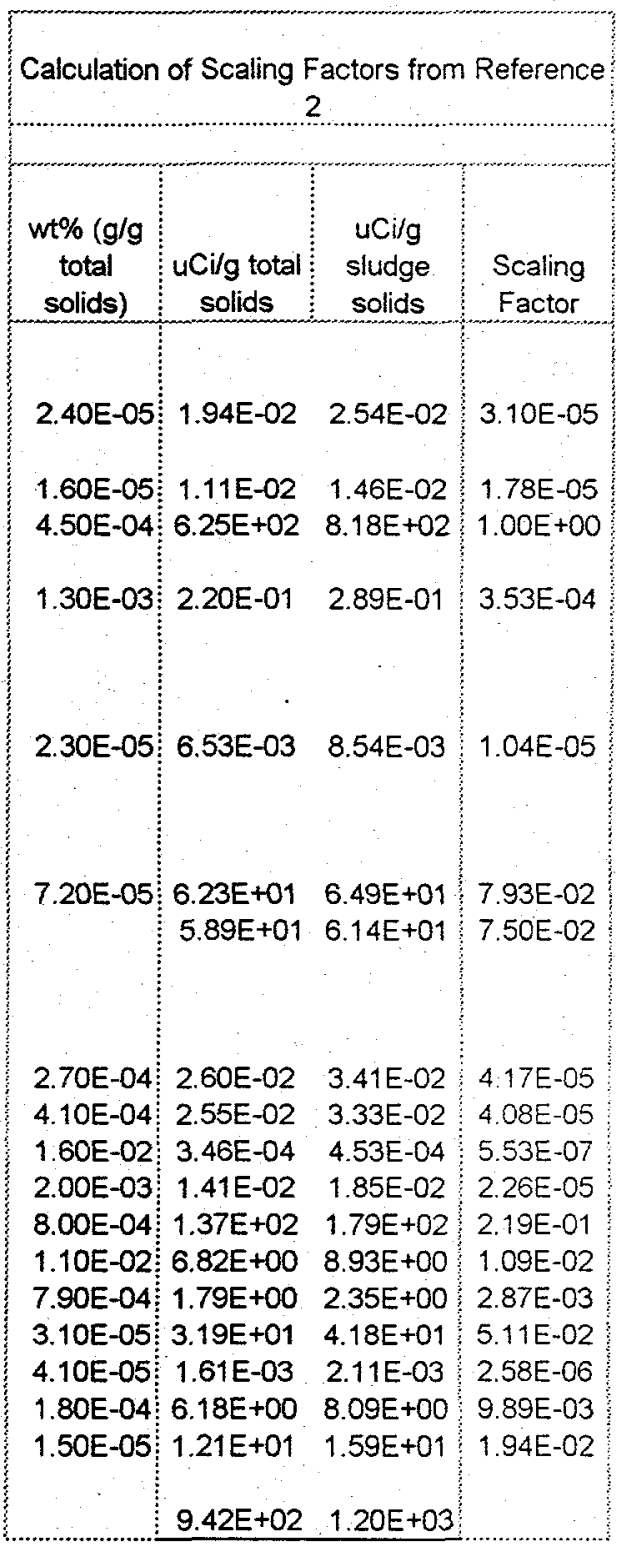


Comparison of Tank 51 PK to Analyzed and WCS-derived Sludge Scaling Factors for Consolidation

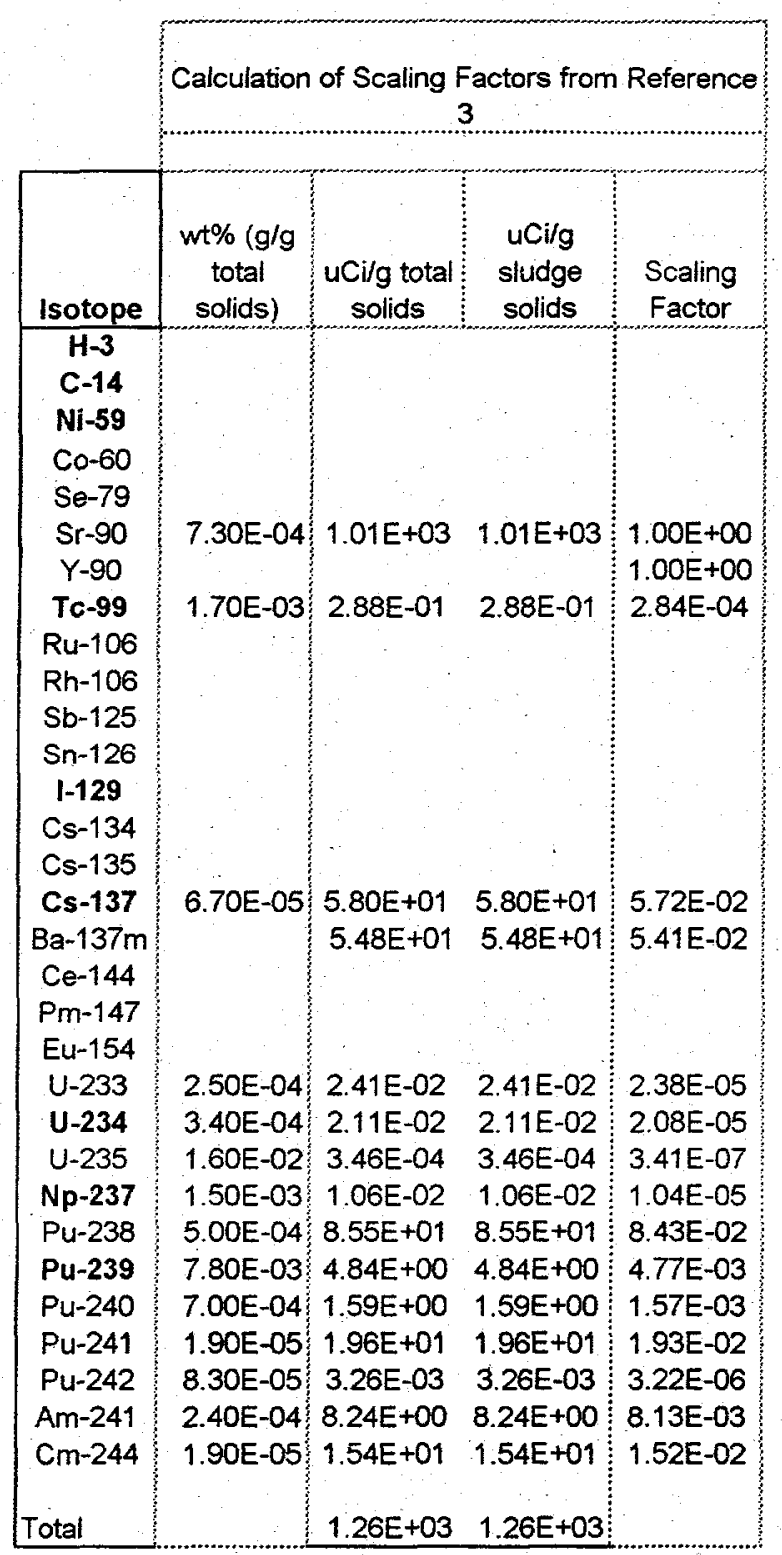

\begin{tabular}{|c|c|c|c|}
\hline \multicolumn{2}{|c|}{$\begin{array}{c}\text { Calculation of Scaling } \\
\text { Factors from WCS } \\
\text { Data (Ref } 4 \text { ) }\end{array}$} & \multicolumn{2}{|c|}{$\begin{array}{l}\text { Calculation of Scaling } \\
\text { Factors from Tank Fill } \\
\text { Data (Ref 5) }\end{array}$} \\
\hline $\begin{array}{l}\text { Tk } 51 \\
\text { WCS } \\
\text { Tables, } \\
\text { Ci/gal }\end{array}$ & $\begin{array}{l}\text { Scaling } \\
\text { Factor }\end{array}$ & $\begin{array}{l}\text { Tk } 51 \text { Fill } \\
\text { Data, } \\
\text { Scaling } \\
\text { Factors }\end{array}$ & $\begin{array}{l}\text { Decay } \\
\text { Corrected } \\
\text { to Year } \\
2000\end{array}$ \\
\hline $2.58 E-07$ & $1.59 E-06$ & $8.22 \mathrm{E}-07$ & 9.29E-07 \\
\hline $1.70 E-05$ & $1.05 E-04$ & 5.29E-05 & 5.98E-05 \\
\hline $5.90 E-04$ & $3.64 \mathrm{E}-03$ & 2.70E-03 & $1.58 E-03$ \\
\hline 2.62E-06 & $1.62 E-05$ & E-06 & 8.32E-06 \\
\hline $1.62 \mathrm{E}-01$ & $1.00 \mathrm{E}+\infty$ & $5.00 E-01$ & 5.00E-01 \\
\hline $1.62 E-01$ & $1.00 \mathrm{E}+\infty$ & & 5.00E-01 \\
\hline 4.49E-05 & $2.77 E-04$ & $E-04$ & 1.43 \\
\hline $1.62 \mathrm{E}-07$ & $9.96 \mathrm{E}-07$ & & 2.36 \\
\hline $1.62 E-07$ & $9.96 \mathrm{E}-07$ & & \\
\hline $1.36 \mathrm{E}-04$ & $8.36 \mathrm{E}-04$ & $=-03$ & 3.14 \\
\hline 3.59E-06 & $2.21 \mathrm{E}-05$ & & 1.19E-05 \\
\hline $1.84 \mathrm{E}-10$ & 1.13E-09 & 5.26E-10 & $5.95 E-10$ \\
\hline 8.76E-06 & $5.40 \mathrm{E}-05$ & 7.55E-05 & $1.58 E-05$ \\
\hline 3.00E-08 & $1.85 \mathrm{E}-07$ & & \\
\hline $9.72 E-03$ & $5.99 E-02$ & $E-02$ & 5.99E-02 \\
\hline $9.20 \mathrm{E}-03$ & $5.67 \mathrm{E}-02$ & $E-02$ & 5.67 \\
\hline 4.15E-08 & 2.56E-07 & $E-06$ & 4.49E-08 \\
\hline $3.23 E-03$ & $1.99 \mathrm{E}-02$ & $2.46 \mathrm{E}-02$ & $7.42 E-03$ \\
\hline $1.99 E-03$ & $1.22 \mathrm{E}-02$ & 37E-01 & 1.25E-02 \\
\hline $4.80 \mathrm{E}-07$ & $2.96 \mathrm{E}-06$ & 43E-07 & $1.61 E-07$ \\
\hline 3.05E-07 & $1.88 \mathrm{E}-06$ & $4.55 E-22$ & $5.15 E-22$ \\
\hline 3.33E-08 & $2.05 \mathrm{E}-07$ & 1.31E-09 & 1.48E-09 \\
\hline $1.87 \mathrm{E}-07$ & 1.15E-06 & 1.95E-06 & $2.21 E-06$ \\
\hline 7.61E-03 & $4.69 \mathrm{E}-02$ & 3.34E-03 & $3.63 E-03$ \\
\hline $8.88 \mathrm{E}-04$ & $5.47 \mathrm{E}-03$ & 3.41E-05 & 3.86E-05 \\
\hline $2.26 \mathrm{E}-04$ & $1.39 \mathrm{E}-03$ & 2.38E-05 & 2.69E-05 \\
\hline 1.15E-03 & $7.06 \mathrm{E}-03$ & $1.08 E-03$ & $9.41 E-04$ \\
\hline 2.64E-07 & 1.63E-06 & 3.46E-08 & $3.92 E-08$ \\
\hline $7.94 \mathrm{E}-05$ & $6.39 \mathrm{E}-04$ & $2.05 E-04$ & $2.30 E-04$ \\
\hline $1.07 \mathrm{E}-06$ & $6.59 \mathrm{E}-06$ & $3.00 \mathrm{E}-06$ & $2.28 E-10$ \\
\hline & & & $1.14 E+00$ \\
\hline
\end{tabular}


Attachment 2

Comparison of Tanks 40, 42 and 51 Consolidation 
Attachment 2

Comparison of Tank 40, 42 and 51 Sludge Isotope Concentrations for Consolidation

\begin{tabular}{|c|c|c|c|c|c|c|}
\hline \multirow[b]{2}{*}{ Isotope } & \multicolumn{3}{|c|}{$\begin{array}{c}\text { Concentration of Isotope in } \\
\text { Insoluble Sludge Solids (uCi/g) }\end{array}$} & \multicolumn{2}{|c|}{$\begin{array}{c}\text { PA Rads, Variation from Mean } \\
\text { Concentration }\end{array}$} & \multirow[b]{2}{*}{$\begin{array}{c}\text { Mean } \\
\text { Distribution }\end{array}$} \\
\hline & Tank 42 & Tank 51 & $\begin{array}{c}\text { Mean } \\
\text { Concentration }\end{array}$ & Tank 42 & Tank 51 & \\
\hline $\mathrm{H}-3$ & & & & & & $0.00 E+00$ \\
\hline C-14 & $5.00 \mathrm{E}-03$ & & $5.00 \mathrm{E}-03$ & $0.00 \%$ & & 6.92E-07 \\
\hline $\mathrm{Ni}-59$ & 7.41E-02 & $2.54 \mathrm{E}-02$ & $4.98 \mathrm{E}-02$ & $48.98 \%$ & $-48.98 \%$ & $6.88 E-06$ \\
\hline Co- 60 & $1.24 E+00$ & $1.28 E+00$ & $1.26 \mathrm{E}+00$ & & & $1.74 E-04$ \\
\hline $\mathrm{Se}-79$ & $9.62 \mathrm{E}-02$ & $1.46 \mathrm{E}-02$ & $5.54 \mathrm{E}-02$ & & & $7.66 \mathrm{E}-06$ \\
\hline$S r-90$ & $5.87 E+03$ & $8.95 E+02$ & $3.38 E+03$ & & & 4.68E-01 \\
\hline$Y-90$ & $5.87 E+03$ & $8.95 E+02$ & $3.38 E+03$ & & & 4.68E-01 \\
\hline TC-99 & $1.89 \mathrm{E}-01$ & $2.88 E-01$ & $2.39 E-01$ & $-20.82 \%$ & $20.82 \%$ & $3.30 E-05$ \\
\hline$R u-106$ & $2.95 E+00$ & & $2.95 E+00$ & & & $4.08 E-04$ \\
\hline Rh-106 & $2.95 E+00$ & & $2.95 \mathrm{E}+00$ & & & $4.08 \mathrm{E}-04$ \\
\hline Sb-125 & $8.32 \mathrm{E}-01$ & & $8.32 E-01$ & & & 1.15E-04 \\
\hline $\mathrm{Sn}-126$ & $3.70 E-02$ & $8.54 E-03$ & $2.28 \mathrm{E}-02$ & & & $3.15 E-06$ \\
\hline $\mid-129$ & $1.23 E-03$ & & $1.23 \mathrm{E}-03$ & $0.00 \%$ & & $1.70 \mathrm{E}-07$ \\
\hline Cs-134 & & & & & & $0.00 E+00$ \\
\hline Cs-135 & $7.76 \mathrm{E}-04$ & & $7: 76 \mathrm{E}-04$ & & & 1.07 E-07 \\
\hline Cs-137 & $1.81 E+02$ & $6.54 E+01$ & $1.23 E+02$ & $46.99 \%$ & $-46.99 \%$ & $1.71 E-02$ \\
\hline $\mathrm{Ba}-137 \mathrm{~m}$ & $1.71 E+02$ & $6.18 \mathrm{E}+01$ & 1.17E+02 & & & 1.61E-02 \\
\hline $\mathrm{Ce}-144$ & $2.61 E+00$ & & $2.61 E+00$ & & & $3.61 E-04$ \\
\hline $\mathrm{Pm}-147$ & & & & & & $0.00 E+00$ \\
\hline Eu-154 & $1.65 E+01$ & $1.86 E+00$ & $9.18 \mathrm{E}+00$ & & & 1.27E-03 \\
\hline U-233 & $4.23 \mathrm{E}-02$ & $3.24 E-02$ & $3.74 \mathrm{E}-02$ & & & 5.17E-06 \\
\hline$U-234$ & $2.91 E-02$ & $3.14 E-02$ & $3.02 E-02$ & $-3.75 \%$ & $3.75 \%$ & $4.18 E-06$ \\
\hline U-235 & $3.67 E-04$ & 4.32E-04 & $4.00 E-04$ & & & 5.53E-08 \\
\hline$N p-237$ & $1.51 E-02$ & $1.45 E-02$ & $1.48 E-02$ & $1.91 \%$ & $-1.91 \%$ & $2.05 E-06$ \\
\hline Pu-238 & $1.09 E+02$ & $1.47 E+02$ & $1.28 E+02$ & & & $1.77 E-02$ \\
\hline Pu-239 & $5.35 E+00$ & $8.26 \mathrm{E}+00$ & $6.80 E+00$ & $-21.40 \%$ & $21.40 \%$ & $9.41 E-04$ \\
\hline Pu-240 & $1.82 E+00$ & $2.51 E+00$ & $2.17 E+00$ & & & $3.00 \mathrm{E}-04$ \\
\hline $\mathrm{Pu}-241$ & $4.19 \mathrm{E}+01$ & $3.07 E+01$ & $3.63 E+01$ & & & $5.02 E-03$ \\
\hline $\mathrm{Pu}-242$ & $3.78 E-03$ & $2.69 \mathrm{E}-03$ & $3.23 E-03$ & & $\therefore$ & 4.47E-07 \\
\hline Am-241 & $7.78 \mathrm{E}+00$ & $8.48 E+00$ & $8.13 E+00$ & & $\therefore$ & $1.13 E-03$ \\
\hline $\mathrm{Cm}-244$ & $6.19 \mathrm{E}+00$ & $3.74 E+01$ & $2.18 E+01$ & & & $3.01 \mathrm{E}-03$ \\
\hline Total & $1.23 E+04$ & $2.15 \mathrm{E}+03$ & $7.23 E+03$ & & & $1.00 E+00$ \\
\hline
\end{tabular}

\begin{tabular}{|c|r|r|r|r|r|}
\cline { 2 - 6 } \multicolumn{1}{c|}{} & \multicolumn{3}{c|}{ Fractional Activity } & \multicolumn{2}{c|}{$\begin{array}{r}\text { Predominant Rads, Variation from Mean } \\
\text { Concentration }\end{array}$} \\
\hline Isotope & Tank 42 & Tank 51 & Concentration & \multicolumn{1}{c|}{ Tank 42 } & Tank 51 \\
\hline Sr-90 & $4.78 \mathrm{E}-01$ & $4.15 \mathrm{E}-01$ & $4.68 \mathrm{E}-01$ & $2.04 \%$ & $-11.24 \%$ \\
Y-90 & $4.78 \mathrm{E}-01$ & $4.15 \mathrm{E}-01$ & $4.68 \mathrm{E}-01$ & $2.04 \%$ & $-11.24 \%$ \\
& & & & & \\
\hline
\end{tabular}

Bold=PA Rads for EAV

*Source=WSRC-TR-94-0562; scaling ratios for Cs-135 developed based on ratio to Cs-137 utilized in Waste Characterization System, which was based on 5-year old waste tables in DPSTD-80-39 "Preliminary Technical Data Summary, DWPF Stage 2," Table 13.6-5, dated 12/80 
WSRC-TR-2000-00115, Rev. 0

Attachment 3

Sludge Waste Stream 40/42/51, Exclusion Criteria 


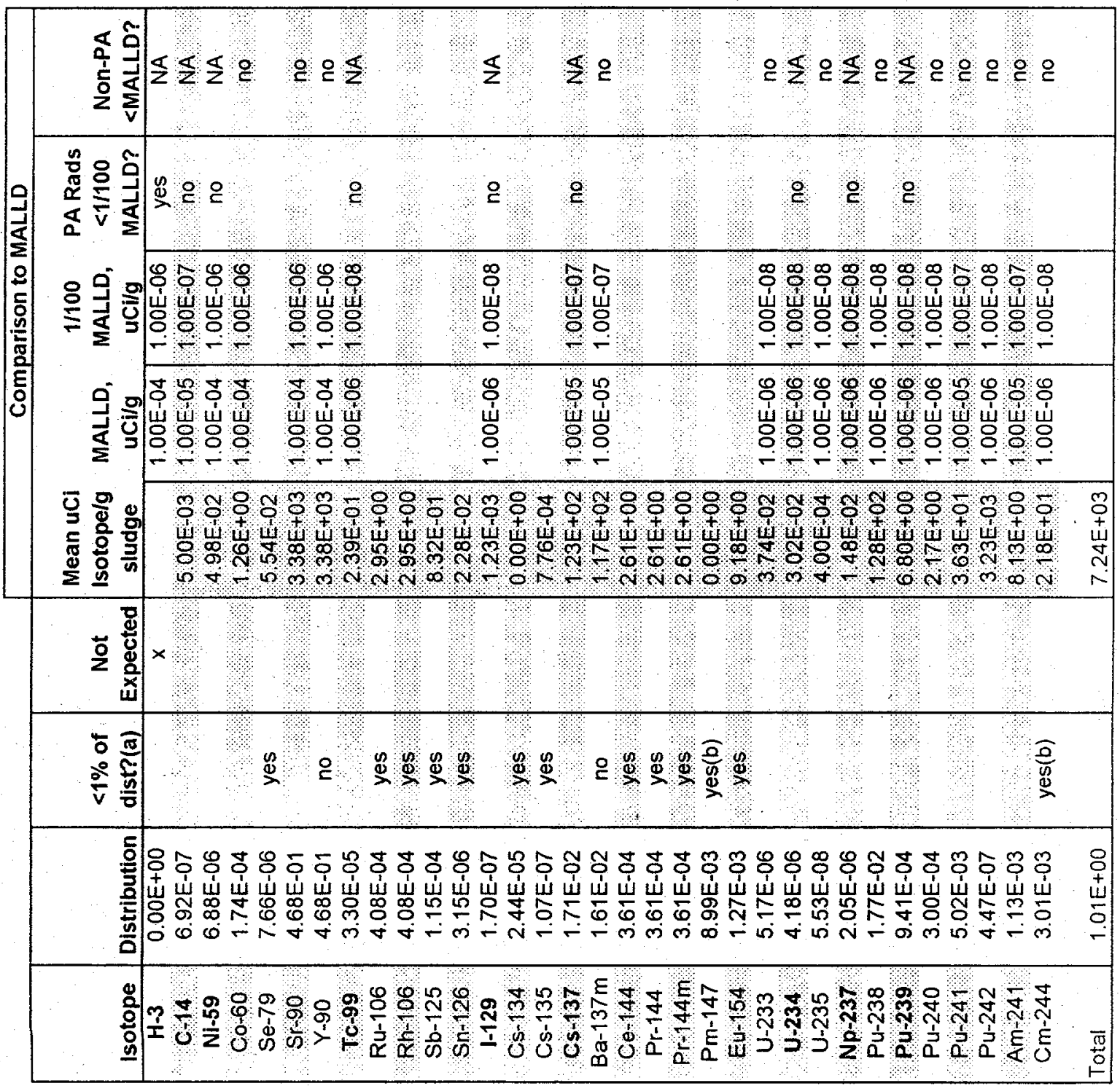


Attachment 4

Sludge Waste Stream 40/42/51, Developing the Final List of Radionuclides 


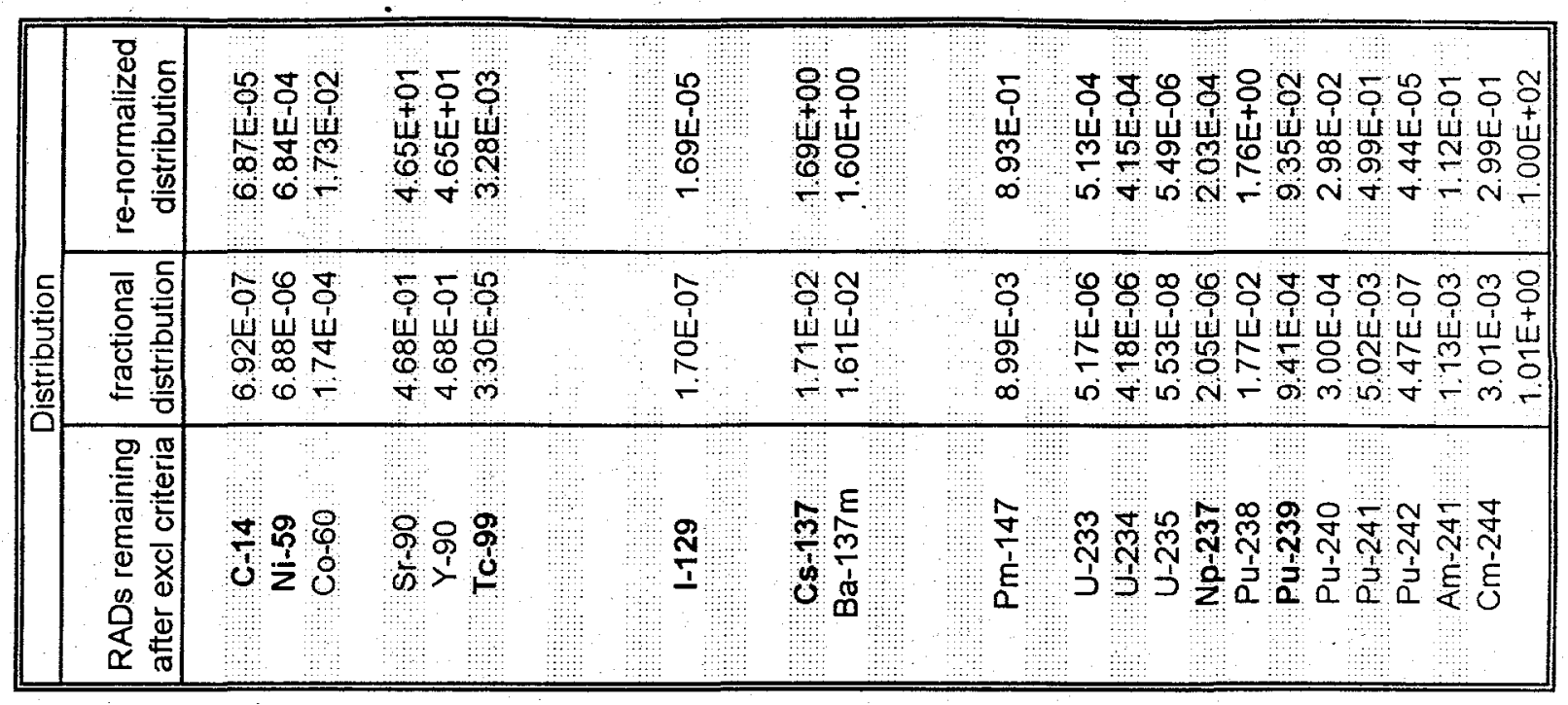

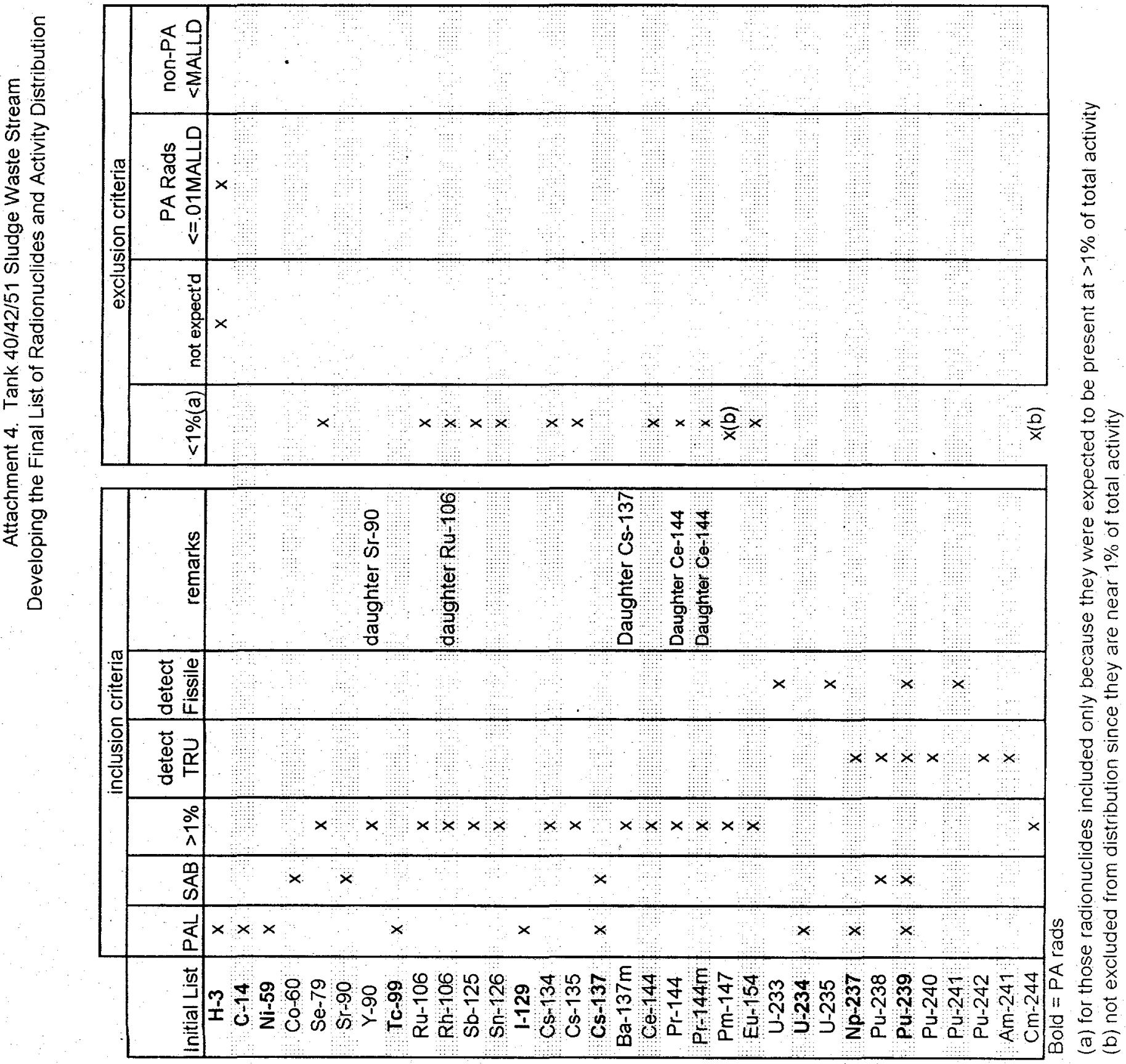


Attachment 5

Waste Characterization Form for Sludge Fraction, WPT-00002-51 
EAV/CIF Low Level Waste Stream Characterization

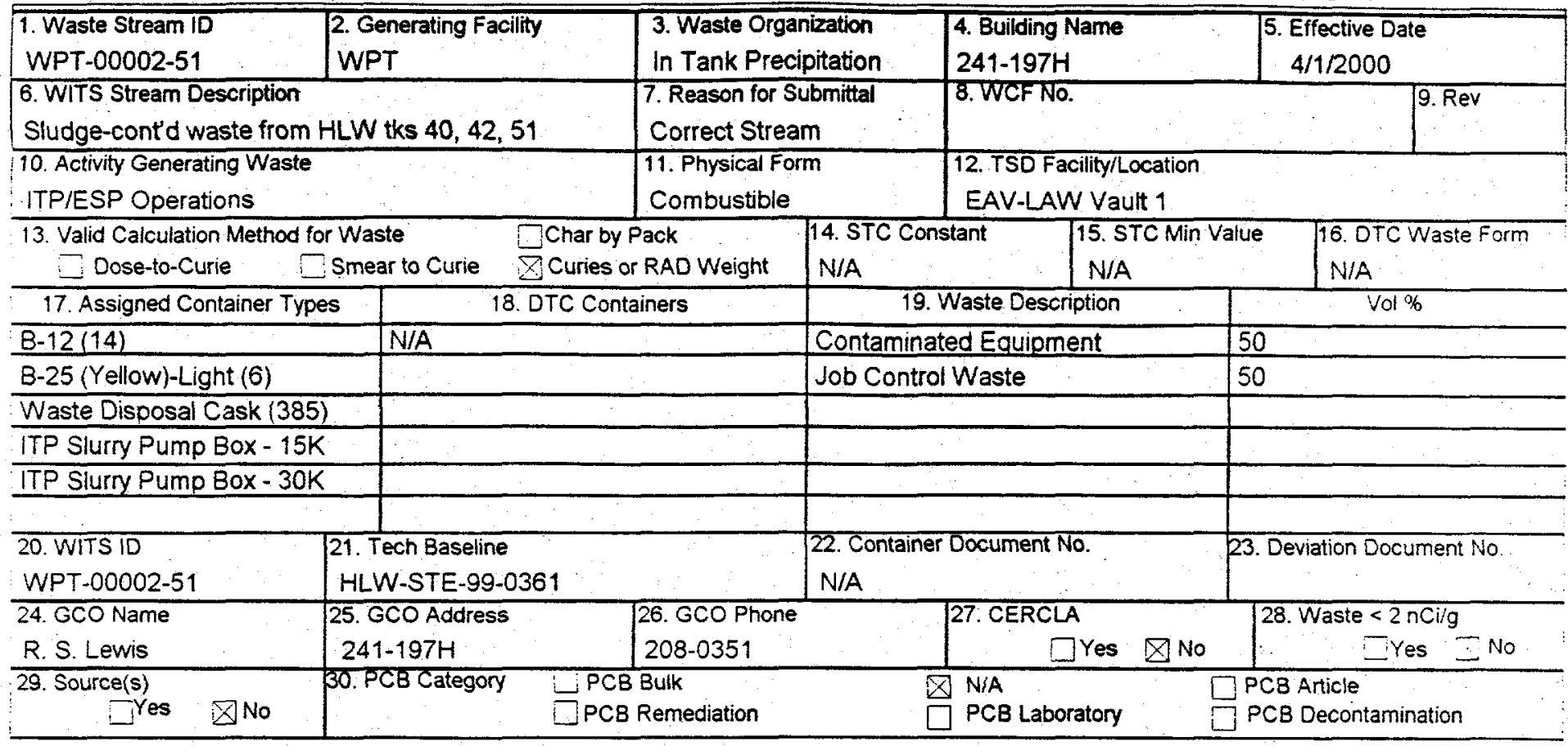

31. Comments

32. Meas Tech

$\triangle$ Process Knowledge

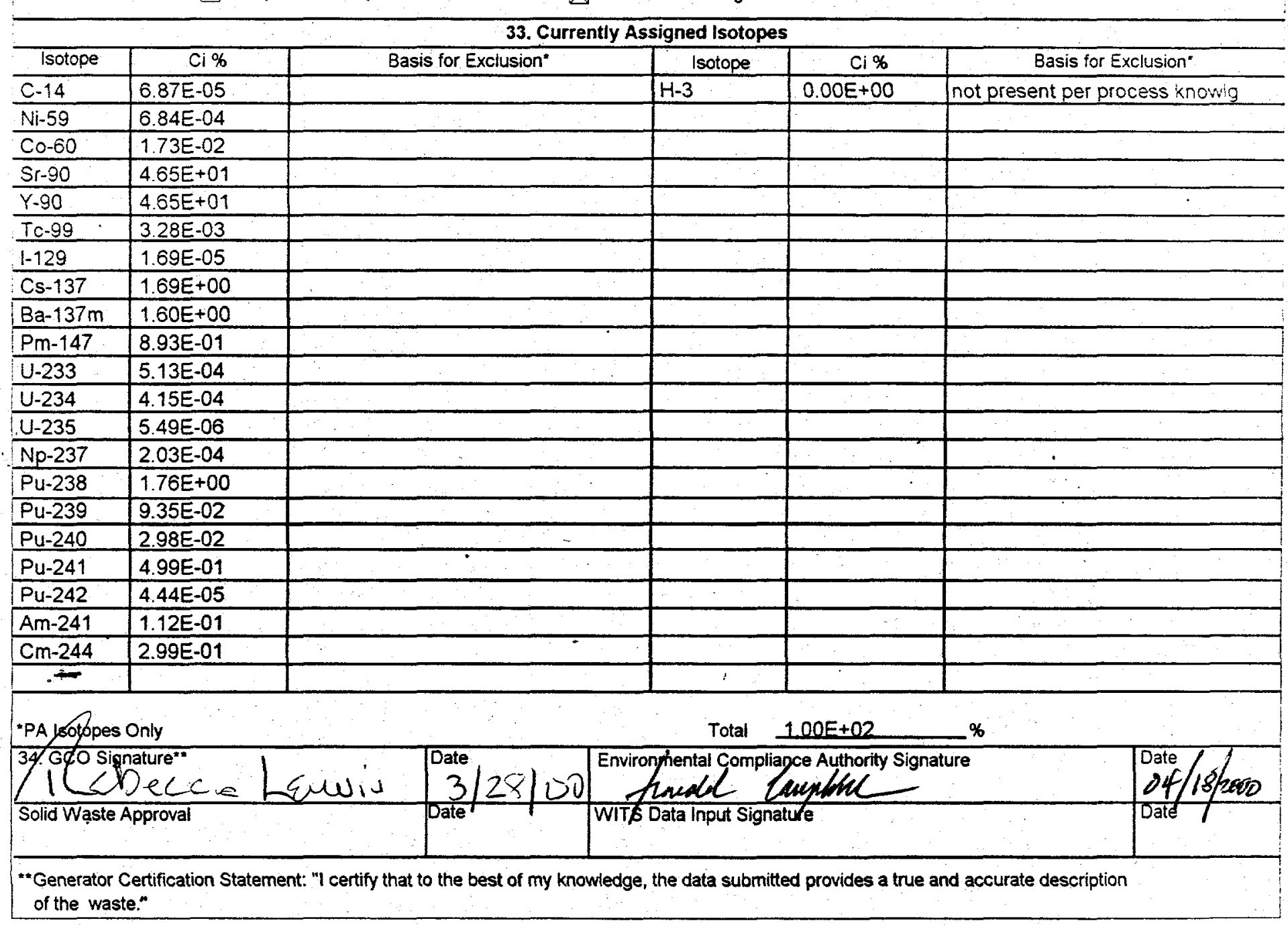




\section{EAV/CIF Low Level Waste Stream Characterization}

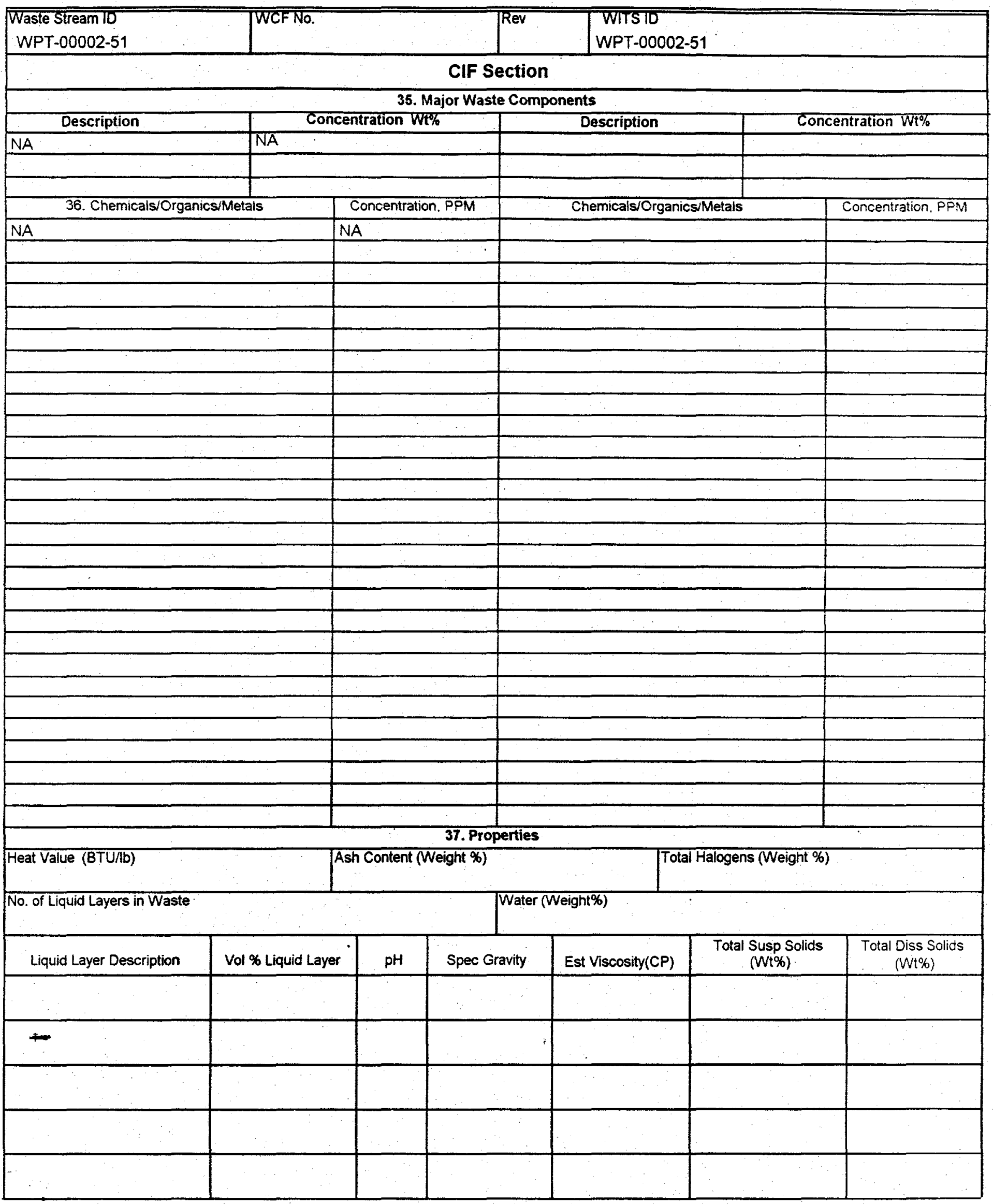


WSRC-TR-2000-00115, Rev. 0

\section{Attachment 6}

Waste Characterization Form for Supernate Fraction, WPT-00001 


\section{EAV/CIF Low Level Waste Stream Characterization}

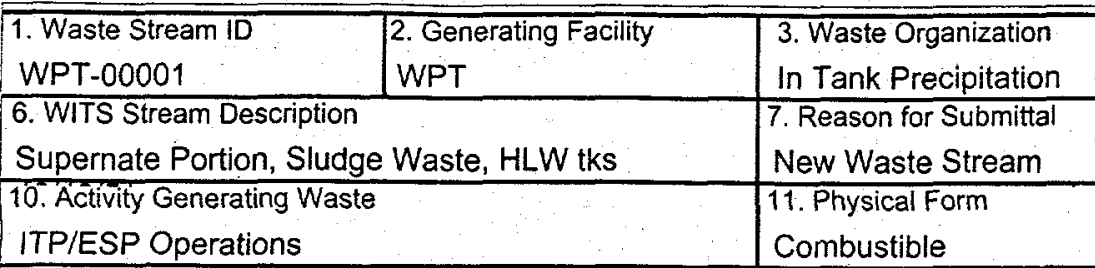

\begin{tabular}{|l|l|l|}
\hline $\begin{array}{l}\text { 4. Building Name } \\
241-197 \mathrm{H}\end{array}$ & $\begin{array}{l}5 . \text { Effective Date } \\
10 / 1 / 99\end{array}$ \\
\hline 8. WCFNo. & 9. Rev \\
\hline $\begin{array}{l}\text { 12. TSD Facility/Location } \\
\text { EAV-LAW Vault } 1\end{array}$ & \\
\hline
\end{tabular}

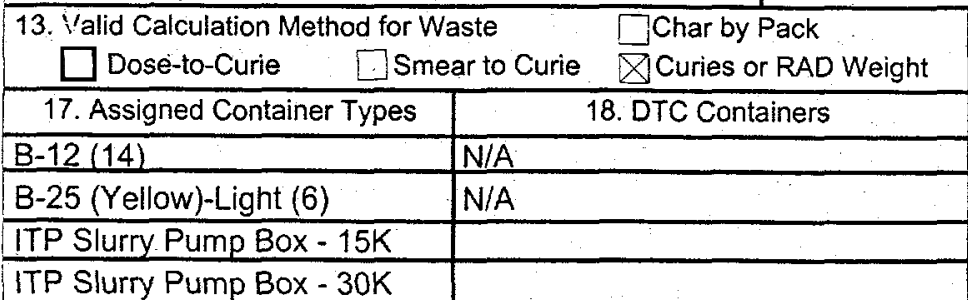

\begin{tabular}{|l|l|l|}
\hline $\begin{array}{l}\text { 14. STC Constant } \\
\text { N/A }\end{array}$ & $\begin{array}{l}15 . \text { STC Min Value } \\
\text { N/A }\end{array}$ & $\begin{array}{l}16 . \text { DTC Waste Form } \\
\text { N/A }\end{array}$ \\
\hline
\end{tabular}

\begin{tabular}{|c|c|c|}
\hline 20. WITS ID & \multicolumn{2}{|l|}{ 21. Tech Baseline } \\
\hline WPT-00001 & \multicolumn{2}{|c|}{ WSRC-TR-94-00290, Rev. 3} \\
\hline 24. GCO Name & 25. GCO Address & 26. GCO Phone \\
\hline R. S. Lewis & $241-197 \mathrm{H}$ & $208-0351$ \\
\hline $\begin{array}{l}\text { 29. Source(s) } \\
\square \text { Yes } \square^{\text {No }}\end{array}$ & 30. PCB Category & $\begin{array}{l}\text { Bulk } \\
\text { Remediation }\end{array}$ \\
\hline
\end{tabular}

\begin{tabular}{|l|l}
\hline Contaminated Equipment & 50 \\
\hline Job Control Waste & 50 \\
\hline &
\end{tabular}

22. Container Document No.

N/A

31. Comments

32. Meas Tech

$\square$ Sample and Analysis

\section{CERCLA}

邓/A

PCB Laboratory 冈rocess Knowledge

\section{Currently Assigned Isotopes}

\begin{tabular}{|l|l|}
\hline \multicolumn{1}{|c|}{ Isotope } & \multicolumn{1}{c|}{$\mathrm{Ci} \%$} \\
\hline $\mathrm{H}-3$ & $2.0 \mathrm{E}-01$ \\
\hline $\mathrm{Co}-60$ & $1.7 \mathrm{E}+00$ \\
\hline $\mathrm{Sr}-90$ & $4.7 \mathrm{E}-02$ \\
\hline $\mathrm{Tc}-99$ & $9.1 \mathrm{E}-03$ \\
\hline $\mathrm{I}-129$ & $1.1 \mathrm{E}-05$ \\
\hline $\mathrm{Cs}-137$ & $5.0 \mathrm{E}+01$ \\
\hline $\mathrm{Ba}-137 \mathrm{~m}$ & $4.7 \mathrm{E}+01$ \\
\hline $\mathrm{U}-233$ & $2.6 \mathrm{E}-04$ \\
\hline $\mathrm{U}-234$ & $7.1 \mathrm{E}-05$ \\
\hline $\mathrm{Pu}-238$ & $2.5 \mathrm{E}-01$ \\
\hline $\mathrm{Pu}-239$ & $2.9 \mathrm{E}-03$ \\
\hline $\mathrm{Pu}-240$ & $1.3 \mathrm{E}-03$ \\
\hline $\mathrm{Pu}-241$ & $1.9 \mathrm{E}-01$ \\
\hline $\mathrm{Am}-241$ & $1.8 \mathrm{E}-02$ \\
\hline & \\
\hline & \\
\hline & \\
\hline & \\
\hline & \\
\hline & \\
\hline & \\
\hline
\end{tabular}

*PA Isotopes Only

34. GCO Signature ${ }^{\star \star}$

Solid Waste Approval

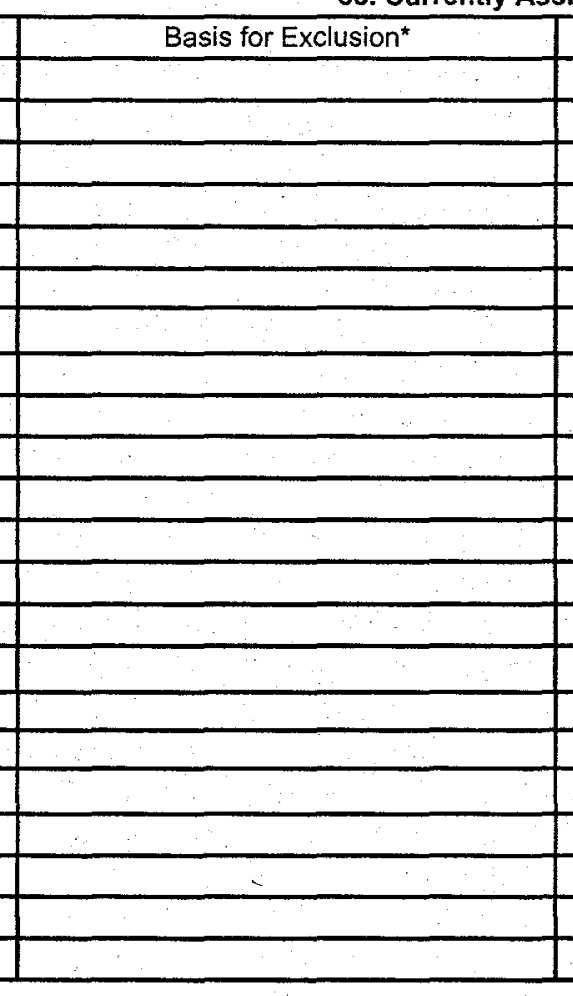

\begin{tabular}{|l}
\hline \\
\hline 50 \\
\hline 50 \\
\hline \\
\\
\hline 23. Deviation Document No. \\
28. Waste < 2 nCi/g \\
$\square$ PCB Article $\square$ Yes $\triangle$ No \\
PCB Decontamination
\end{tabular}

$\square$ Yes $\triangle$ No

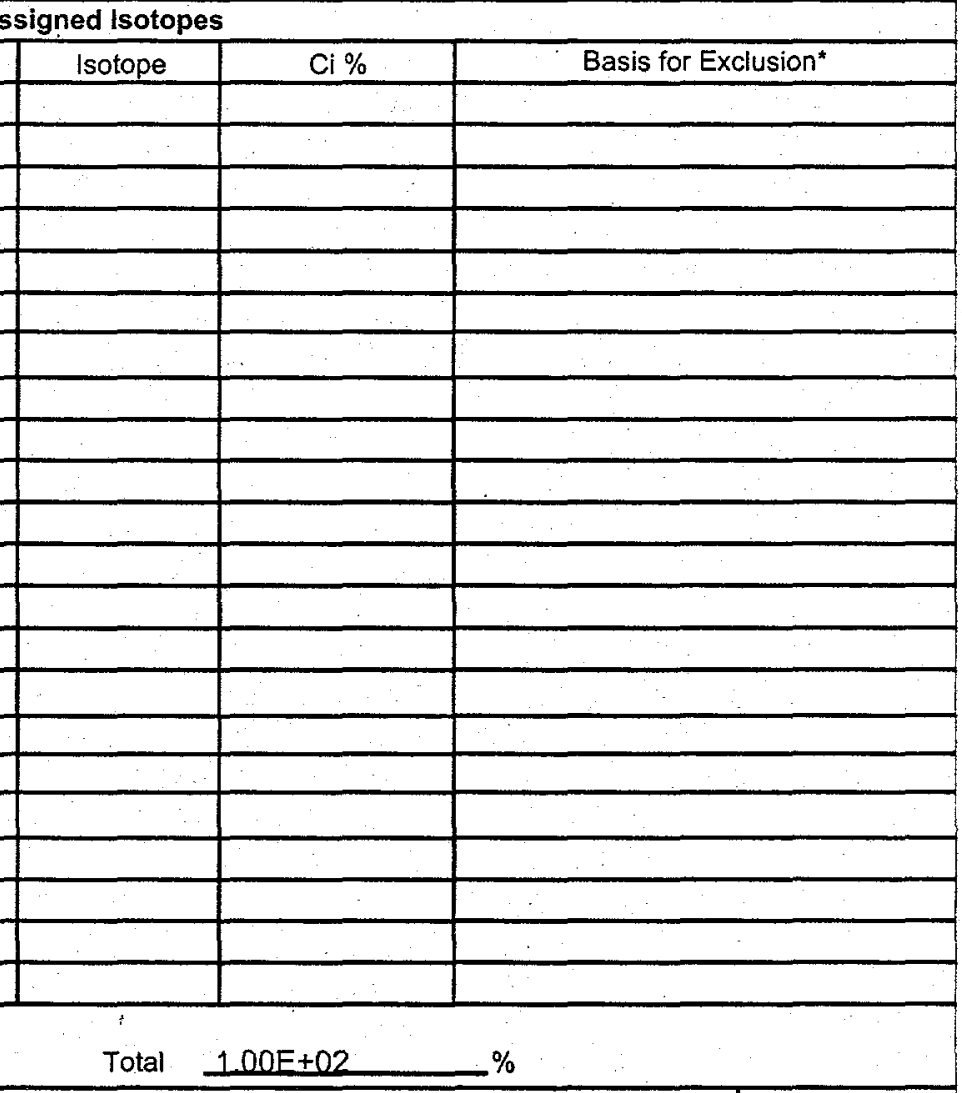

Environmental Compliance Authority Signature

WITS Data Input Signature

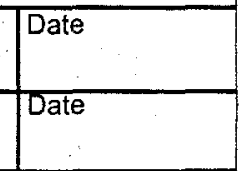

** Generator Certification Statement: "I certify that to the best of my knowledge, the data submitted provides a true and accurate description of the waste." 


\section{EAV/CIF Low Level Waste Stream Characterization}

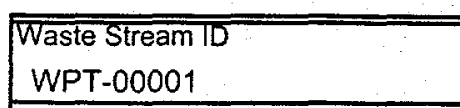

WPT-00001

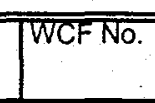

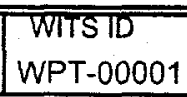

\begin{tabular}{|l|l} 
Rev & $\begin{array}{l}\text { WITS ID } \\
\text { WPT-00001 }\end{array}$ \\
\hline
\end{tabular}

CIF Section .

35. Major Waste Components

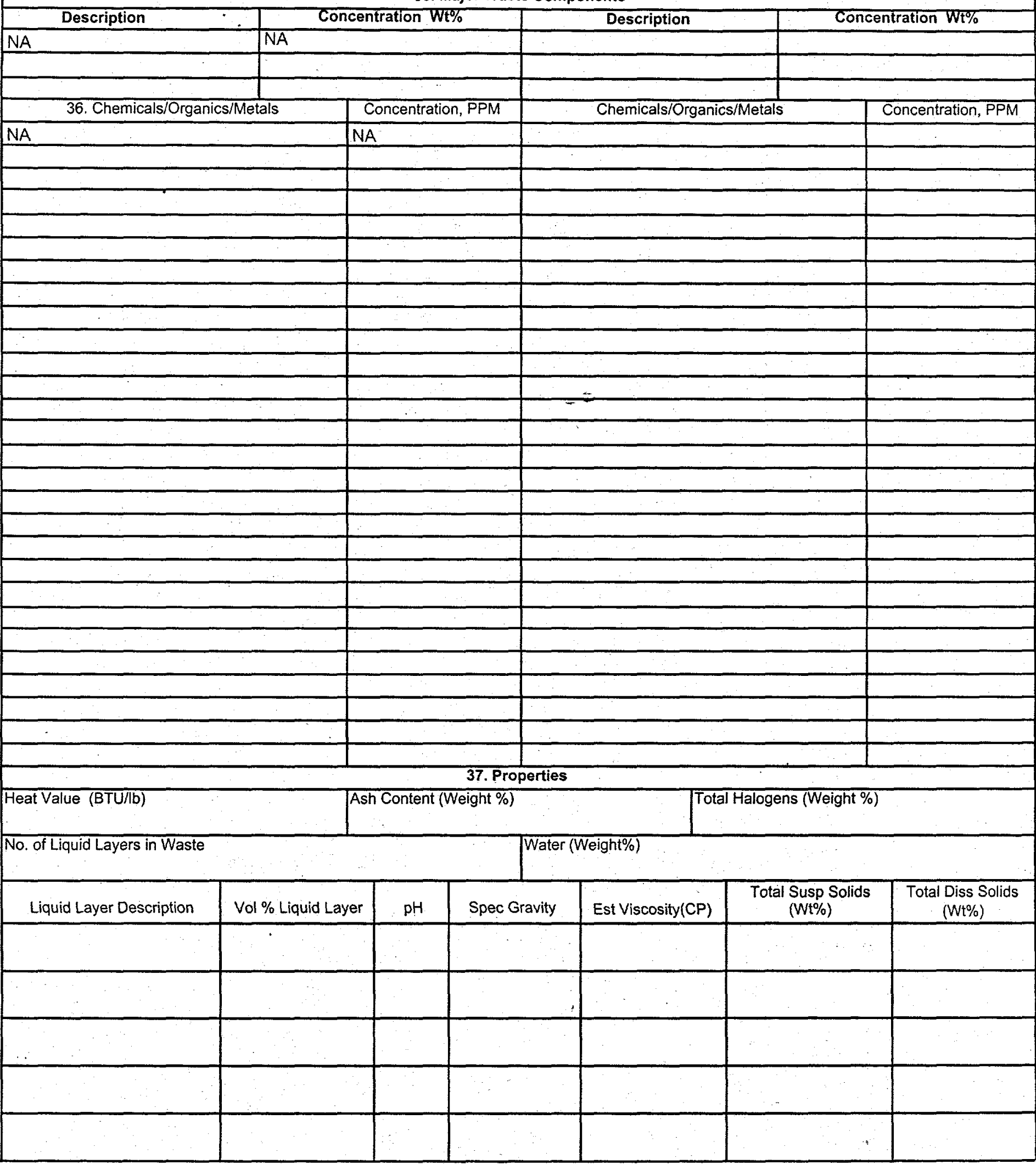


WSRC-TR-2000-00115, Rev. 0

Attachment 7

Sludge Waste Stream 40/42/51, Sludge and Supernate Fractions Activity Distributions 


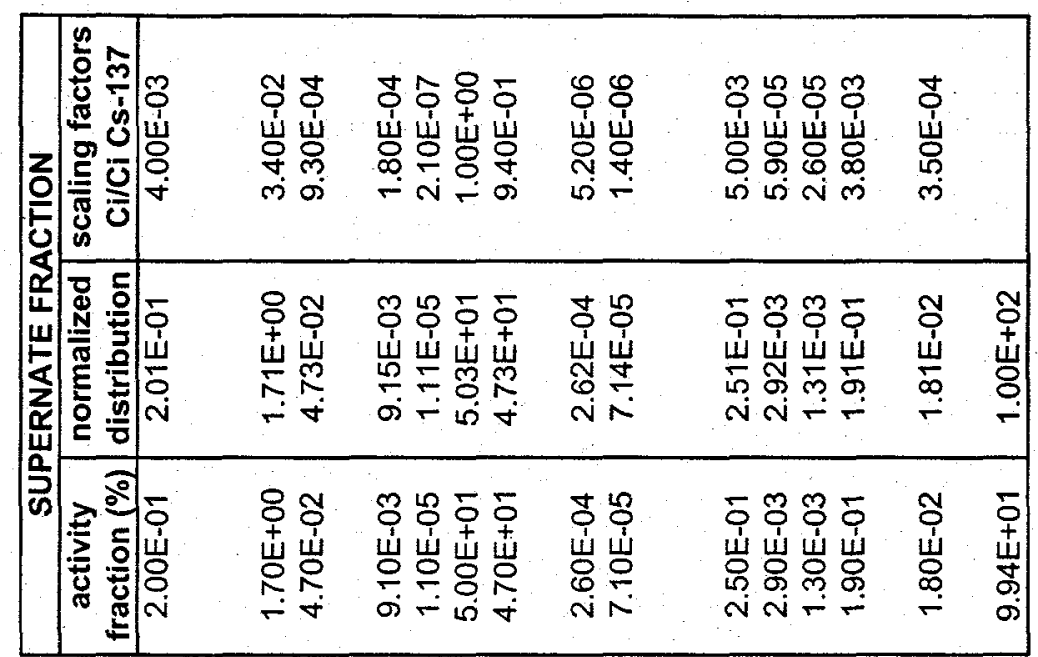

\begin{tabular}{|c|c|}
\hline 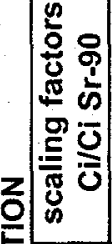 & 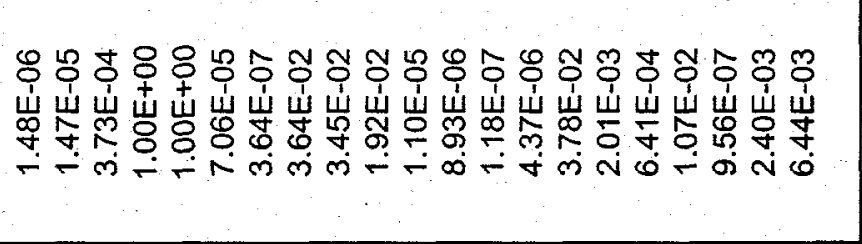 \\
\hline 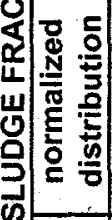 & 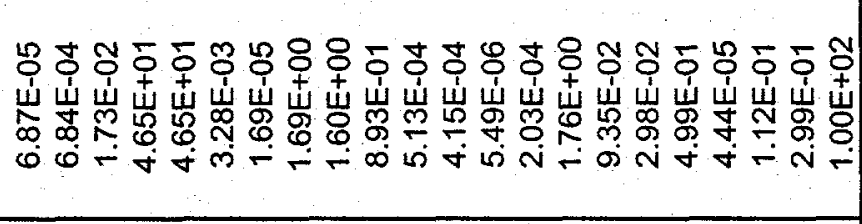 \\
\hline$\frac{\pi}{0}$ & 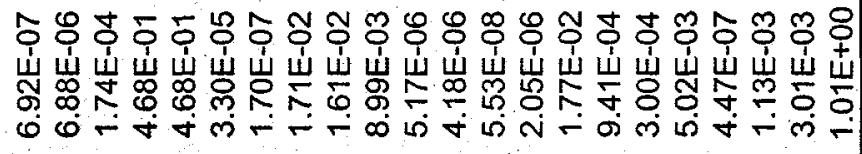 \\
\hline
\end{tabular}

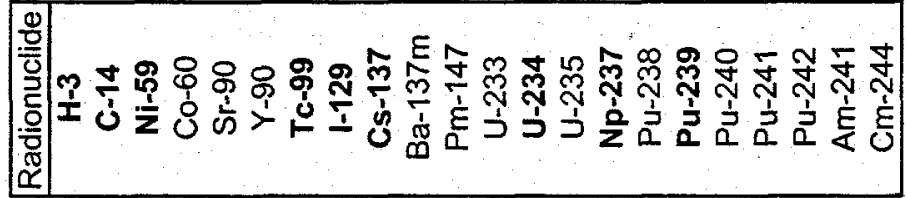

